\title{
1. INTRODUCTION TO THE NORTH ATLANTIC-ARCTIC GATEWAYS: PLATE TECTONIC-PALEOCEANOGRAPHIC HISTORY AND SIGNIFICANCE ${ }^{1}$
}

\author{
Jörn Thiede² and Annik M. Myhre
}

\begin{abstract}
The Arctic and Subarctic seas exert major influences on global climate and ocean systems. The oceanic pathways between the Arctic Ocean proper and the North Atlantic Ocean provide passages for shallow and deep-water exchange and thus contribute to patterns and variability of ocean and atmospheric circulation over this segment of the Northern Hemisphere. Because of the global importance of these processes, the Ocean Drilling Program (ODP) had designed a program to study the geological and paleoceanographic history of these passages defined as North Atlantic-Arctic Gateways (NAAG). Under the framework of this program, ODP Leg 151 investigated the western Norwegian-Greenland Sea (Iceland Plateau and East Greenland Margin), the Fram Strait (Hovgård Ridge and the deep sill between the Arctic Ocean and the Norwegian-Greenland Sea), and several locations on the Yermak Plateau to the north of Svalbard. ODP Leg 162 comprised the second part of this program and was carried out in late summer 1995. It concentrated on drill sites to the north and south of the Greenland-Scotland Ridge as well as in the Norwegian-Greenland Sea; its northernmost location was to the west of Svalbard in an attempt to drill one of the troughmouth fans of glacial origin.

The major success of the NAAG drilling program has to be sought in (1) a complete and detailed coverage of the preglacial paleoceanography of the Norwegian-Greenland Sea; (2) the identification of the onset of the ice cover in the northern North Atlantic to the south of the Greenland-Scotland Ridge, in the western Norwegian-Greenland Sea, in Fram Strait, and on Yermak Plateau; and (3) the description of patterns of variability of sedimentation in response to the cyclical behavior of the depositional environment (Milankovitch frequencies). In this volume the scientific results of ODP Leg 151 (July to September 1993) are presented.
\end{abstract}

\section{THE SIGNIFICANCE OF THE NORTH ATLANTIC- ARCTIC GATEWAYS}

Planet Earth has experienced an extended history of long- and short-term climatic variability. Even though climate has usually varied within a relatively narrow band, geological evidence suggests that Earth experienced several periods of cold climates that led to largescale glaciations of polar regions. In Figure 1 some of the peculiarities of the Cenozoic cold global climates are depicted. During the Cenozoic, the planet's interior dynamics that drive plate tectonics subdivided Earth's surface into rather small oceanic and continental compartments. Furthermore, during the middle and late Cenozoic, the drift of the plates resulted in a situation with isolated physiographic provinces that developed over both polar regions: the Arctic Ocean in the northern polar region and the small continent Antarctica in the southern polar region. Contrary to this latest example, all other cold climate developments in Earth's history coincided with rather different plate-tectonic settings. As far as can be documented in terms of paleogeography, in most cases a giant continent developed over one of the poles, while the opposite pole was located in the vast expanse of a deep ocean, allowing the advection of water masses from temperate latitudes and preventing bipolar glaciation. The poorly understood exception of the old examples is the late Precambrian glaciation, whose traces can be found in so many places that no clearly de-

'Thiede, J., Myhre, A.M., Firth, J.V., Johnson, G.L., and Ruddiman, W.F. (Eds.). 1996. Proc. ODP, Sci. Resuits, 151: College Station, TX (Ocean Drilling Program). ${ }^{2}$ GEOMAR, Research Center for Marine Geosciences, Wischhofstraße 1-3, D24148 Kiel, Federal Republic of Germany.jthiede@geomar.de

${ }^{3}$ Department of Geology, Universitetet i Oslo, Postboks 1047, Blindern, N-0316 Oslo, Norway. fined regional picture has been developed (Frakes, 1979). One of the unique properties of the Cenozoic example is the bipolar glaciation, although the peculiar physiography has led to important differences in the type and pattern of variability of glacial ice cover on the northern and Southern Hemisphere.

Furthermore, the plate tectonic evolution has led to an unusual temporal coincidence in the development of the Southern and Northern Hemispheres. In general terms, the evolution of the circum-Antarctic Southern Ocean was completed when the continental margins of Antarctica and the plateau south of Australia that carried Tasmania parted along a large transform system that allowed them to bypass each other while this part of the Southeast Indian Ridge was opening. This event seems to have occurred during magnetic Anomaly 13 time. The unresolved opening of the Drake Passage and Scotia Sea, however, may have occurred much later, in the Miocene (Lawver et al., 1992). In the Northern Hemisphere, the continued opening of the North Atlantic first propagated into the Labrador Sea/Baffin Bay area during the late Mesozoic and earliest Cenozoic. Only with the onset of the Cenozoic did the ridge axis that led to the development of the Norwegian-Greenland Sea begin to open. Later seafloor spreading in the Labrador Sea and Baffin Bay area died out (Srivastava, 1985), and since Anomaly 24 time (Talwani and Eldholm, 1977), we see a stepwise opening of the Norwegian-Greenland Sea and the adjacent eastern Arctic Basin. The evolution and subsidence of the GreenlandScotland Ridge, as well as the complicated tectonic evolution of Fram Strait, exercise major controls on the evolution of surface and deep-water channels connecting the Arctic Ocean proper and the main basin of the North Atlantic Ocean. The transform movement of the Greenland-Svalbard margin also gave way to seafloor spreading, after a change in the pole of rotation of the North American-Greenland/Eurasian plates approximately during Anomaly 13 time (Talwani and Eldholm, 1977). 
Figure 1. Subdivision of the Holocene world into terrestrial and oceanic compartments, with the Arctic Ocean in the northern and Antarctica in the southern polar position (Broecker and Denton 1990). Continental ice sheets (in black) and sea icecover (in gray) roughly corresponding to the last glacial maximum are indicated for both hemispheres.

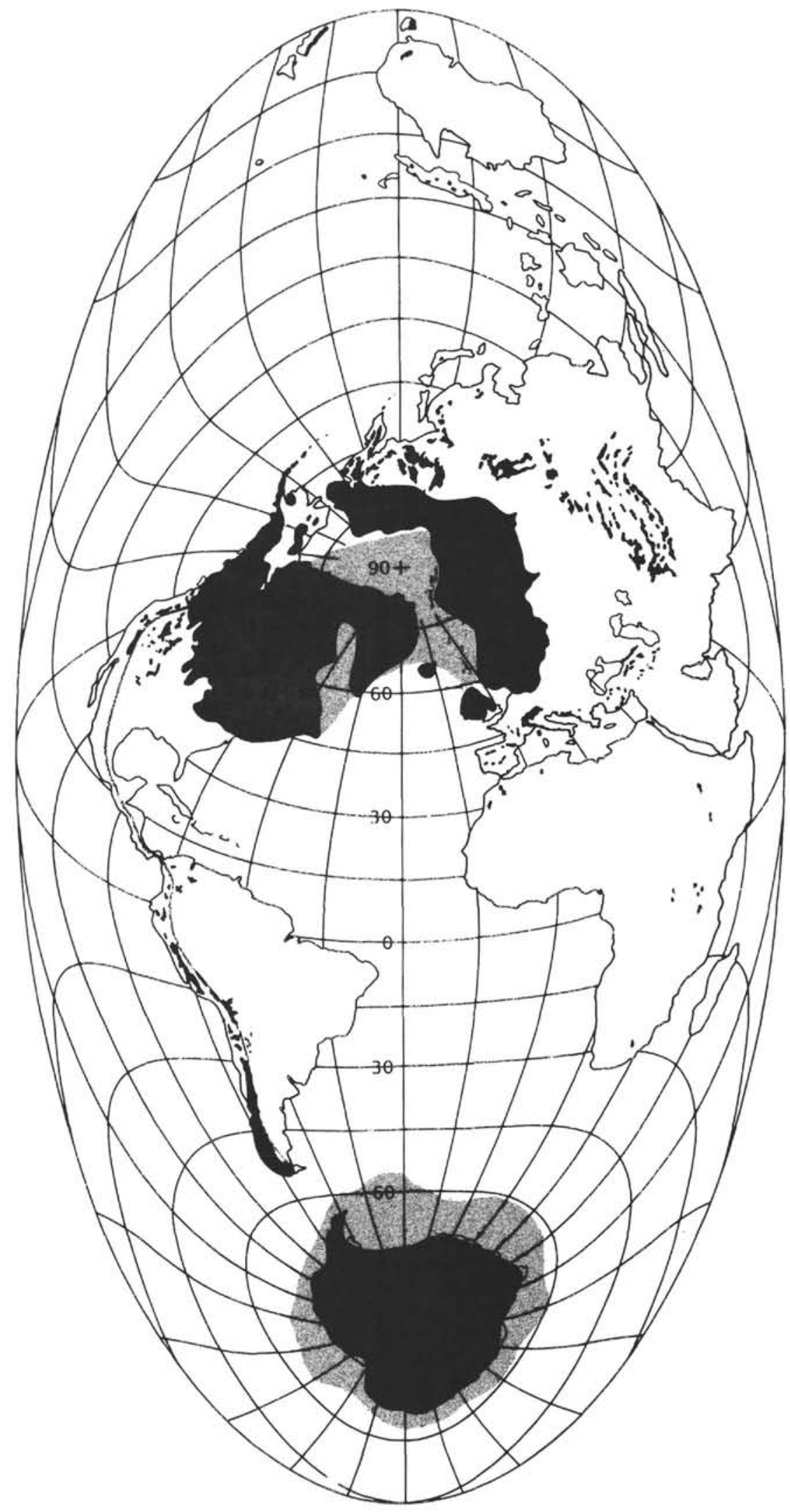




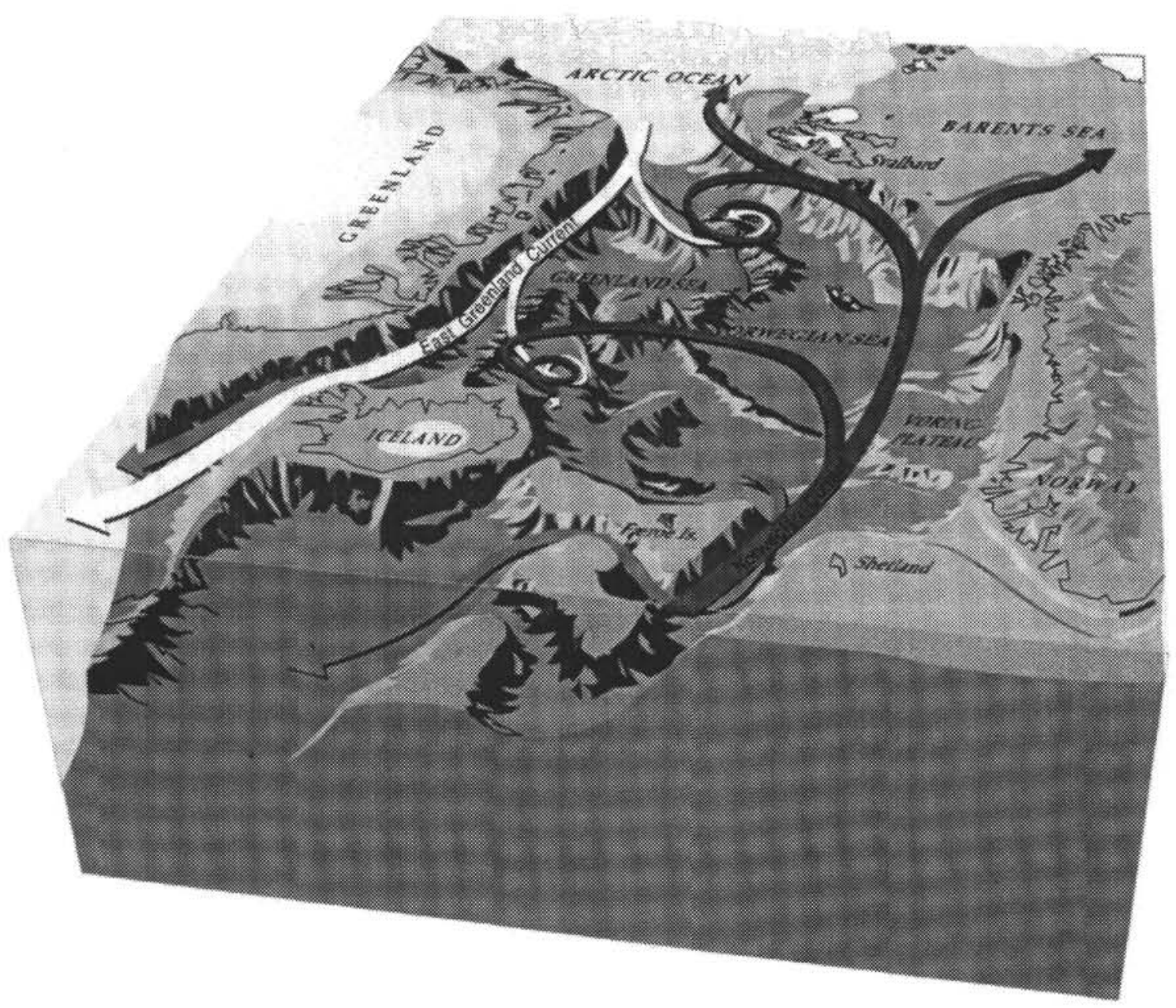

Figure 2. Physiographic diagram of the Norwegian-Greenland Sea, including the gateways from the North Atlantic Ocean into the Norwegian-Greenland Sea (Greenland-Scotland Ridge) and from the Norwegian-Greenland Sea into the Arctic Ocean (Fram Strait). Although the current systems and their patterns of advection are shown schematically only, the diagram illustrates vividly how important the Norwegian-Greenland Sea is for shallow- and deep-water exchange of the major oceanic water masses in the North Atlantic Ocean (computer graphics by Masaocki Adachi, Dept. Geol., Univ. Bergen/Norway).

Because of the peculiar physical properties of seawater close to freezing, the Arctic and Subarctic basins and, in particular, the evolution of the passages to the North Atlantic have been of major importance for the delivery of such waters to the entire world ocean. The Greenland Basin and the circum-Arctic shelf areas are regions where surface-water masses become dense enough to sink to the bottom of the deep-sea basins, thereby renewing the bottom-water masses. Together with a similar area, the Weddell Sea, in Antarctica, these can be considered the lungs of the world ocean because the dense and cold water masses transport large quantities of dissolved oxygen into the deep sea, spreading out from there into lower latitudes (Broecker 1995). In general, the majority of the oceanic deep-water masses obtain their major hydrographic properties in these areas.

In Figure 2, we illustrate characteristic elements of the modern surface and deep-water circulation in the Norwegian-Greenland Sea. Even in this simplified version it can be seen how the complicated morphology of the deep-sea basins and the adjacent continental margins, as well as the two major elements of this North Atlantic-Arctic Gateway (NAAG), the Greenland-Scotland Ridge and its channels and Fram Strait, are guiding these water masses. An extension of the Gulf Stream/North Atlantic Drift system enters the eastern side of the Norwegian-Greenland Sea (here called the Norwegian Current), following the Norwegian continental margin and passing the Vøring
Plateau, whose sediment cover was sampled during Ocean Drilling Program (ODP) Leg 104. To the north of the Fennoscandian peninsula it subdivides into a branch turning east and a branch continuing along the Barents Sea continental margin, bypassing Svalbard until it enters the Arctic Ocean proper to dive under the Arctic sea-ice cover. This current system, which is advecting considerable quantities of temperate water masses into the Norwegian-Greenland Sea on its way to the north, is balanced by the East Greenland Current, which is carrying cold, partly ice-covered, brackish water from the Arctic Ocean along the East Greenland continental margin to the south, until it leaves the Norwegian-Greenland Sea through the Denmark Strait and by the deep water that is renewed in the Norwegian-Greenland Sea and that spills across the Greenland-Scotland Ridge (for example through the Faeroe-Shetland Channel) to feed the North Atlantic Deep Water (NADW).

Building on the success of Leg 104 (Eldholm, Thiede, Taylor, et al., 1987; 1989), which established the history of the Norwegian Current, the NAAG Program of ODP was to study the paleoenvironmental history of the entire system. Two legs were devoted to the program: Leg 151, which was conducted in July to September, 1993 (Myhre, Thiede, Firth, et al., 1995), tried to address the western and northern elements of this system, whereas Leg 162, in the late summer of 1995, put heavy emphasis on the southern and central ele- 


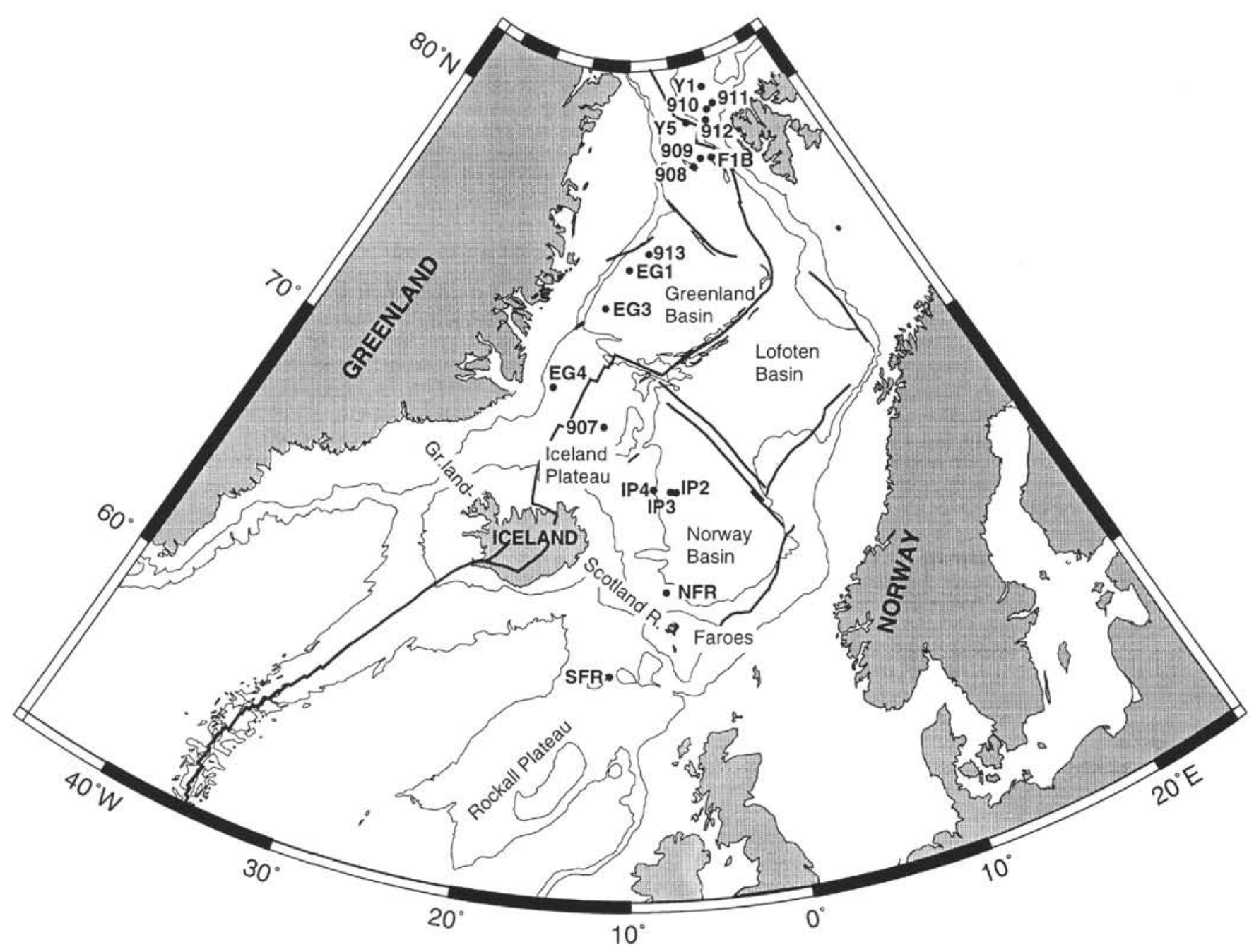

Figure 3. Simplified bathymetric map of the Norwegian-Greenland Sea with locations of proposed sites and drill sites of ODP Leg 151.

ments of the circulation system (Jansen, Raymo, Blum, et al., 1996) In this volume we have compiled detailed scientific investigations based on data and samples obtained during Leg 151 (Myhre, Thiede, Firth, et al., 1995). These results have to be seen in conjunction with the results of Leg 162 (which have been published under separate cover as an ODP Initial Reports volume), but which contain valuable information on the area and partly on our sites. Both legs of the ODP NAAG program, however, comprise a package of elements of the same scientific objectives and can be considered as one of the most successful scientific approaches addressing a problem with major consequences for the well-being of all of Earth's inhabitants. The locations of Legs 151 and 162 are shown in Figures 3 and 4.

\section{MODERN PHYSIOGRAPHY AND ITS MAIN ELEMENTS}

The present-day physiography of the Norwegian-Greenland Sea and southernmost part of the Arctic Ocean strongly reflects the plate tectonic evolution through the Cenozoic. The Norwegian-Greenland Sea and southern part of the Arctic Ocean (Fig. 5) consist of several deep basins separated by major fracture zones, the Jan Mayen, Greenland-Senja, and Spitsbergen fracture-zone systems. The active spreading axis, the Kolbeinsey, Mohns, Knipovich, and Gakkel ridg- es, further contribute to a segmentation of the deep basins. In addition, structural elements like microcontinents and marginal plateaus, such as the Jan Mayen, Hovgård, and Lomonosov ridges, the Vøring and Yermak plateaus and the Morris Jesup Rise, are all positive structures standing well above the surrounding seafloor (Fig. 5).

To the south, the Norwegian-Greenland Sea is restricted toward the North Atlantic Ocean by the shallow, transverse Greenland-Scotland Ridge. This aseismic volcanic structure is part of the large volcanic province extending from Baffin Island across Greenland, the Faeroes, and to the British Isles. The sill depth between Iceland and East Greenland, in the Denmark Strait, is only $600 \mathrm{~m}$. The flat-topped ridge between Iceland and the Faeroes has a water depth between 400 and $600 \mathrm{~m}$, while the deepest part of the ridge can be found between the Faeroe and Scottish shelves, in the Faeroe-Shetland Channel with water depths between 900 and $1000 \mathrm{~m}$ (Fig. 6).

The deep Norway Basin (Fig. 6), north of the Greenland-Scotland Ridge in the eastern part of the Norwegian Sea, has a maximum water depth exceeding $3800 \mathrm{~m}$ along the extinct rift axis that was active between anomalies 24 and 7 time. The Norway Basin is bounded by the shallow Iceland Plateau and the Jan Mayen Ridge to the west, the Norwegian margin toward the east, and the eastern part of the Jan Mayen Fracture Zone toward the north. The shallow Iceland Plateau is a flat-topped platform defined by the $1800-\mathrm{m}$ contour. It is bounded by the Norway Basin and Jan Mayen Ridge toward the east, while the 


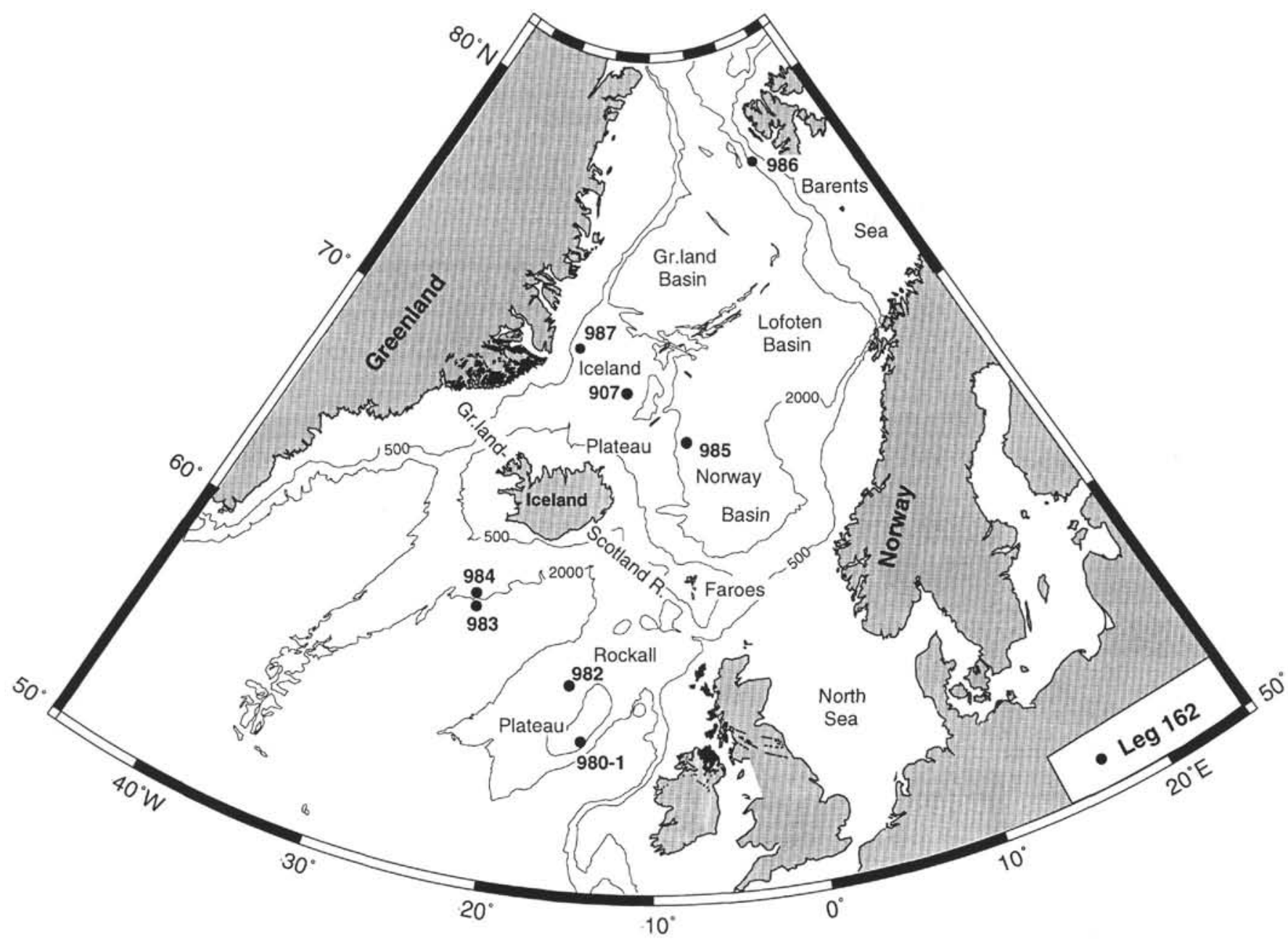

Figure 4. Simplified bathymetry of the northern North Atlantic, of the Greenland-Scotland Ridge, and of the adjacent Norwegian Greenland Sea, with drill sites of ODP Leg 162.

active spreading axis along the Kolbeinsey Ridge defines the western boundary close to the Greenland margin. To the north, the western segment of the Jan Mayen Fracture Zone represents the transition to the deep Greenland Basin. The Jan Mayen Ridge is a flat-topped 275 $\mathrm{km}$-long, north-south-trending structure defined by the $1000-\mathrm{m}$ isobath.

The Greenland and Lofoten basins north of the Jan Mayen fracture-zone system are situated symmetrically about the Mohns Ridge spreading axis and both basins have well-developed abyssal plains. The average water depth of the Lofoten Basin is about $3200 \mathrm{~m}$, somewhat shallower than the Greenland Basin, where the basin floor lies between the 3600- and 3700-m isobaths (Fig. 6; Perry, 1986). The difference in water depth might be explained by a difference in influx of sediments.

The location of the Knipovich Ridge active spreading axis is asymmetrically situated in the Greenland Sea (Fig. 5) at about $78^{\circ} \mathrm{N}$, abutting the lower slope of the Svalbard margin. Between the Svalbard shelf and the Knipovich Ridge there is no abyssal plain developed. The tremendous late Tertiary outbuilding of the Svalbard shelf and slope have led to a thick sequence of sediments onlapping and partially drowning the axial mountains. The Boreas Basin, however, west of the Knipovich Ridge, has a small, well-developed abyssal plain at a depth of approximately $3000-3200 \mathrm{~m}$ (Fig. 6), about $600 \mathrm{~m}$ shallower than the Greenland Basin. The difference in water depth has been ascribed to a younger crustal age of the Boreas Basin (Eldholm and Windisch, 1974) but could also be explained by a thicker sediment cover. The Boreas Basin is restricted by the Greenland Fracture Zone to the south and by the Hovgård Ridge microcontinent to the north.

The northwest-southeast-trending Hovgård Ridge microcontinent is situated just north of $78^{\circ} \mathrm{N}$ and divides the Greenland Sea in two separate basins: the Boreas Basin to the south and the GreenlandSpitsbergen Sill Basin to the north. The Hovgård Ridge consists of two morphological elements: the northernmost is a flat-topped ridge with a minimum water depth of $1171 \mathrm{~m}$ (Eldholm and Myhre, 1977) and the southernmost is a seamount-like feature with a minimum water depth of $1307 \mathrm{~m}$. The Greenland-Spitsbergen Sill Basin has an average water depth of $2500 \mathrm{~m}$. This basin is restricted to the east and northwest by the northern termination of the Knipovich Ridge and the Spitsbergen transform system, which transfers the spreading axis into the Gakkel Ridge in the Arctic ocean. The transform system consists of the Molloy Fracture Zone, Molloy Ridge, and Spitsbergen Fracture Zone, and Lena Trough, which appears to curve and continue directly into the Gakkel Ridge (Fig. 5).

For a more detailed description of the physiography and various structural elements we refer to Myhre and Thiede (1995).

\section{PLATE TECTONIC EVOLUTION}

A first-order plate tectonic framework was given by Talwani and Eldholm (1977) who showed that seafloor spreading started in the 
Norwegian-Greenland Sea in the early Tertiary; the oldest seafloor spreading magnetic anomaly they identified was Anomaly 24B. Seafloor spreading started between Anomaly 25 and 24B about $55 \mathrm{Ma}$, close to the Paleocene/Eocene boundary. A similar age has been suggested for the onset of seafloor spreading in the Arctic-Eurasia Basin, with the oldest identified seafloor-spreading anomaly also being Anomaly 24 (Vogt et al., 1979).

The opening of the Norwegian-Greenland Sea took place in a region where the crust had already been stretched and thinned by repeated rift phases from late Paleozoic through Paleocene times. The most important extensional phase before the final rifting and breakup in Late Cretaceous-Paleocene times is the Late Jurassic-Early Cretaceous rift event. During this period, deep basins were formed off mid-Norway and in the western Barents Sea, with a thickness of Cretaceous sediments ranging between 6 and $10 \mathrm{~km}$. The final rift phase began in the latest Cretaceous at about Campanian-Maastrichtian time and led to complete continental separation and seafloor spreading at the Paleocene/Eocene boundary.

The margins surrounding the Norwegian-Greenland Sea are characterized as volcanic passive margins and lie within the North Atlantic Volcanic Province (NAVP), extending from the Charlie-Gibbs Fracture Zone at about $55^{\circ} \mathrm{N}$ to the Svalbard margin at $75^{\circ} \mathrm{N}$ (Fig. 7).

Considerable late syn-rift uplift took place in the central rift zone before the onset of igneous activity. This created an extensive land area between Greenland and Norway, which became a major source for the Paleocene sediments deposited in the Møre and Vøring basins. The rifting episode lasted for about 18 m.y. (Skogseid et al., 1992) and the final breakup was accompanied by the emplacement of both onshore flood basalts and massive extrusive complexes along the continent-ocean transition. A more than $300-\mathrm{km}$-wide rift zone was affected by the igneous activity (Skogseid, 1994), and this had a profound influence on the Norwegian-Greenland Sea area with respect to both structural and paleoenvironmental evolution (Eldholm and Thomas, 1993). The volcanic pulse abated shortly after seafloor spreading started and the spreading axis subsided below sea level with separate deep basins evolving in the middle Eocene. According to Eldholm (1990), they were probably isolated to a large extent throughout the Paleogene.

The incipient plate boundary between Eurasia and Greenland consisted of two mega lineaments, the Reykjanes-Mohns rift zone between the Charlie-Gibbs and Greenland-Senja fracture zones and the regional shear zone the De Geer Zone (Harland, 1969) between the western Barents Sea, Svalbard, and northeast Greenland. The segmentation of the Norwegian-Greenland Sea was governed by these two mega lineaments, which gave rise to northeast-trending rifted, margin elements in the southern part and a northwest-trending complicated pattern of sheared, rifted, and shear/rifted margin segments in the northern part (Fig. 8).

The plate tectonic evolution of the Norwegian-Greenland Sea can be divided into two major phases. From break-up, between Anomaly 25 and 24, and through the Eocene to Anomaly 13 time, Greenland moved in a northwesterly direction with respect to Eurasia, which is reflected in the azimuths of the Jan Mayen, Senja, and Greenland fracture zones. The three major basins in the Norwegian Sea, the Lofoten, Greenland, and Norway basins (Fig. 6), developed to deep basins through the Eocene. No well-developed seafloor-spreading anomalies have so far been identified in the Greenland Sea, but, based on plate reconstructions, Eldholm et al. (1987) showed that seafloor spreading probably started as early as Anomaly 24 time in the southern part of the Greenland Sea. At the end of the Eocene a deep basin had been created in the soathernmost part of the Greenland Sea. To the north, however, a transpressional regime developed along the northern part of the plate boundary between Greenland and Spitsbergen creating the Spitsbergen Thrust and Fold Belt.

At Anomaly 13 time seafloor spreading stopped in the Labrador Sea, and Greenland became part of the American plate. After this

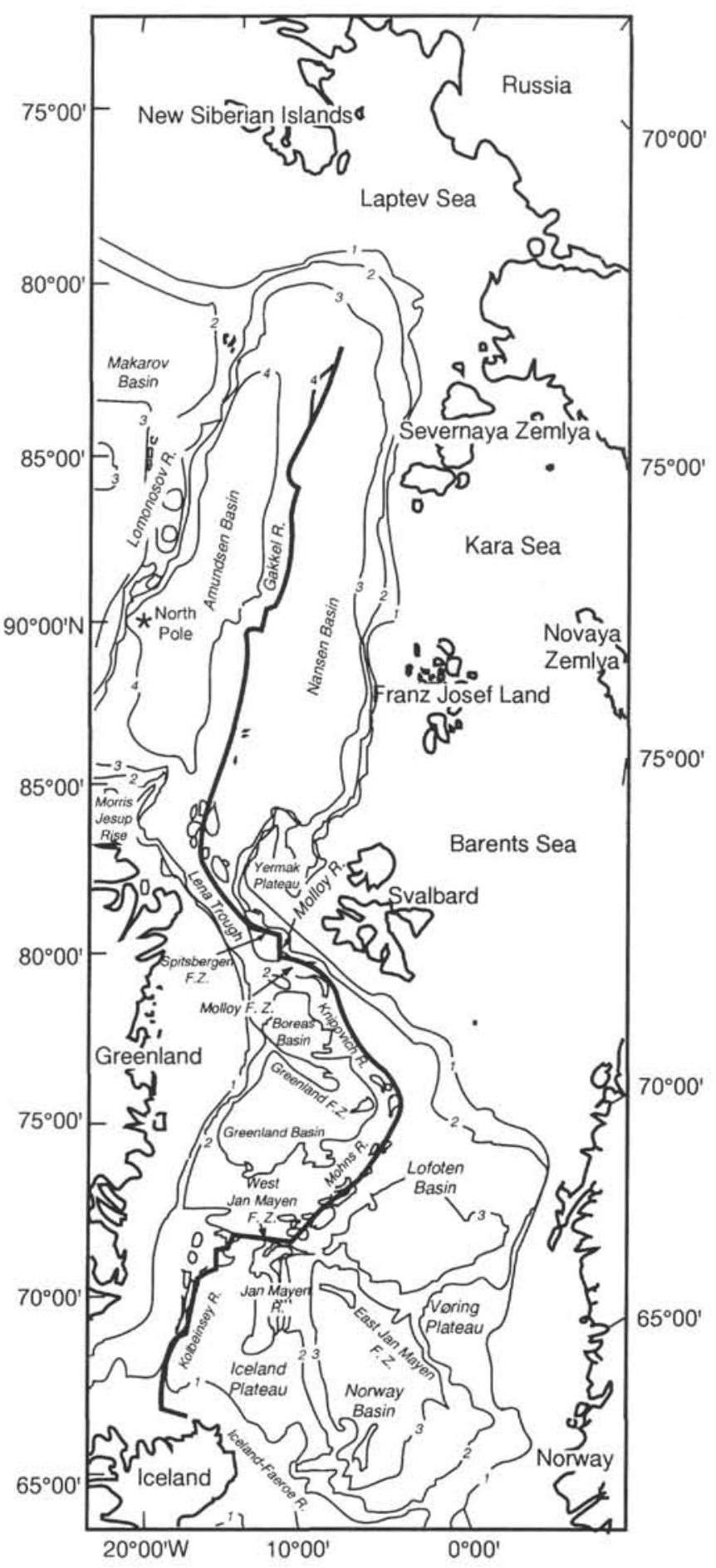

Figure 5. Main physiographic and structural elements in the NorwegianGreenland Sea and eastern Arctic Ocean (Eldholm et al., 1990). Simplified bathymetry (Perry et al., 1985).

plate tectonic reorganization and change in poles of rotation, Greenland began to move in a more westerly direction leading to rifting and finally seafloor spreading in the northern Greenland Sea.

Plate tectonic reconstruction of the Eurasia Basin before Anomaly 13 does not leave enough space for a major part of the Yermak Plateau and Morris Jesup Rise (Figs. 5, 8), and a volcanic origin has been 


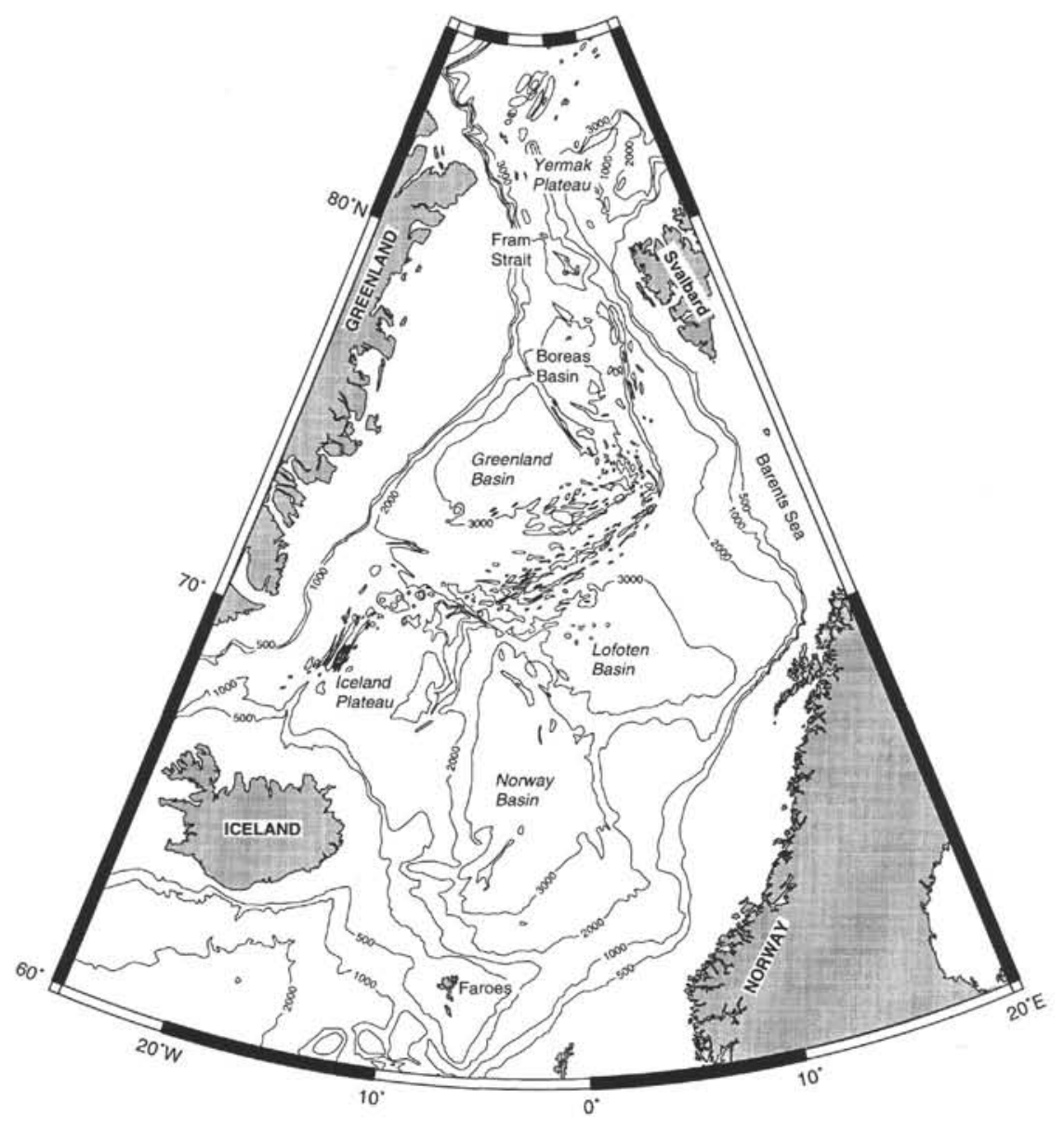

Figure 6. Bathymetry of the Nordic Seas (Perry et al., 1980).

suggested for them. Feden et al. (1979) explained the structures by a hot-spot origin between Anomaly 18 and 13 (middle Eocene to earliest Oligocene), creating a major, probably subaerial, volcanic structure between Svalbard and Greenland. It appears that, with the plate tectonic reorganization at Anomaly 13 time, the large igneous activity died out and the spreading axis subsided to normal oceanic depths leaving behind the two marginal volcanic plateaus. The timing of the subsidence of the two aseismic plateaus also had a major influence on the deep-water circulation between the Arctic Ocean and the Norwegian-Greenland Sea.

With respect to the plate tectonic evolution, the NorwegianGreenland Sea can be divided into three major provinces. The area between the Greenland-Scotland Ridge and the Jan Mayen fracturezone system had a complicated evolution with a westward migration of the spreading axis through time. In the Norway Basin the extinct Ægir Ridge was active until Anomaly 7 time, when spreading gradually died out and a westward shift of the axis took place. The westward jump led to splitting off of the Jan Mayen microcontinent from East Greenland. Talwani and Eldholm (1977) have proposed a shortlived spreading axis on the Iceland Plateau from about Anomaly 6B to $5 \mathrm{D}$, before another westward shift and the present-day Kolbeinsey Ridge came into existence. Vogt et al. (1980), however, do not believe in the intermediate axis and have suggested that the new postAnomaly 7 axis developed into the Kolbeinsey Ridge. With the model of Talwani and Eldholm (1977), Site 907 was drilled on crust with an age of about 22 Ma but with the model of Vogt et al. (1980), the site was drilled on crust with an age between 14 and $15 \mathrm{Ma}$.

The region between the Jan Mayen and Greenland-Senja fracture zones (Fig. 8) had a relatively simple evolution, and only minor ad- justments of the plate boundary took place before Anomaly 23 time, with the Greenland and Lofoten basins developing almost symmetrically along the Mohns Ridge.

The Greenland Sea, however, appears to have a complicated evolution that is not very well understood. Weak seafloor spreading anomalies exist in the southern Greenland Sea, but in the northern part, in the Fram Strait area, the magnetic field is remarkably quiet. The asymmetric position of the Knipovich Ridge also suggests one or several jumps or adjustments of the spreading axis through time. The major part of multichannel seismic data that were collected in the Greenland Sea is along the western Barents Sea-Svalbard margin, but because of the thick Neogene sedimentary sequence, there are still several unsolved questions with respect to the location and nature of the continent/ocean boundary.

At Anomaly 13 time, the transpressional regime in the northern Greenland Sea area changed to a tensional regime and rifting commenced. It was suggested by Myhre et al. (1982) and Myhre and Eldholm (1988) that the Hovgård Ridge microcontinent was cut off from the Svalbard margin during the opening of the northern Greenland Sea. The age and extent of oceanic crust north of the Hovgard Ridge is not well documented, and an important question is how long did the rift phase last before the Hovgarrd Ridge was completely released from the Svalbard margin, and oceanic crust and a deep-water connection were created east and north of the microcontinent? Several suggestions have been made for the opening and initiation of the deep-water connection in the northern Greenland Sea through the Fram Strait. The various models span from the early Oligocene to the late Miocene (Crane et al., 1982; Eldholm et al., 1987; Lawver et al., 1990; Eldholm, 1990; Kristoffersen, 1990a; Myhre et al., 1995). 


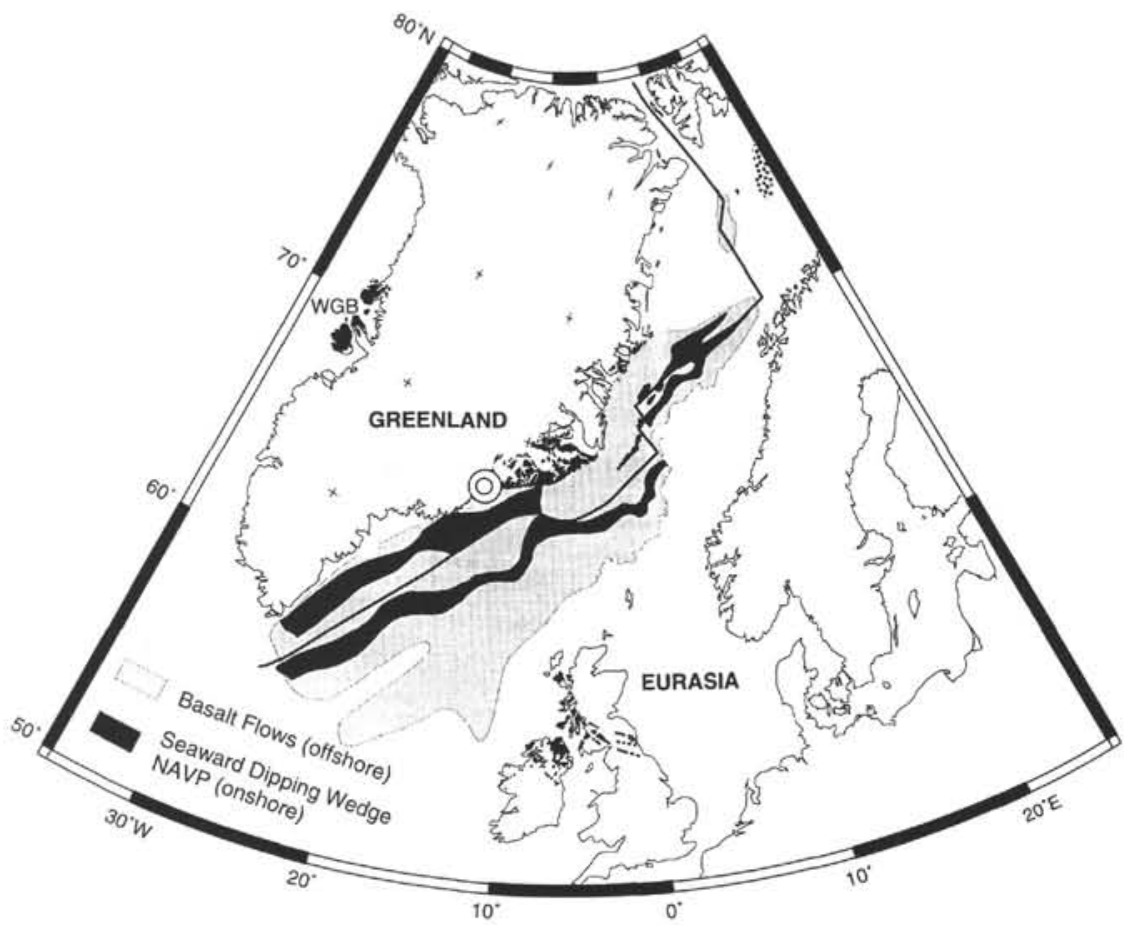

Figure 7. Extent of the North Atlantic Volcanic Province at magnetic Anomaly 23 time (Eldholm and Thomas, 1993). Hot-spot location (double circle) from White and McKenzie (1989).

\section{VOLCANIC AND TECTONIC HISTORIES OF THE GREENLAND-SCOTLAND RIDGE AND OF FRAM STRAIT}

\section{Greenland-Scotland Ridge}

The Greenland-Scotland Ridge is an anomalous, shallow bathymetric feature between Greenland, Iceland, the Faeroes, and Scotland (Fig. 9). It can be classified as an aseismic ridge except for where the active mid-ocean spreading axis transects Iceland. The ridge represents a shallow barrier, a gateway, between the North Atlantic and the Norwegian-Greenland Sea. The ridge has been formed by an excessive production of volcanic material and is underlain by anomalous thick crust that is close to $30 \mathrm{~km}$ thick near the Faeroes but thins slightly toward Iceland (Bott, 1983a).

Morphologically, the aseismic structure can be divided into three parts: (1) the Greenland-Iceland Ridge, or Denmark Strait, with a sill depth of $600 \mathrm{~m}$, where the continental margins of Greenland and Iceland almost merge, separated only by the 20 - to $30-\mathrm{km}$-wide Denmark Strait Channel; (2) the Iceland-Faeroe Ridge between Iceland and the Faeroes, which is nearly $300 \mathrm{~km}$ long and about $200 \mathrm{~km}$ wide, forms a plateau-like 400 - to 600 -m-deep area with a smooth crest, and is separated from the Icelandic and Faeroe shelves by short bathymetric scarps (Bott, 1983a); and (3) the 900- to 1000-m-deep Faeroe-Shetland Channel east of the Faeroes toward the Scottish shelf (Fig. 9).

The crustal age of the Denmark Strait is close to $50 \mathrm{~m} . \mathrm{y}$. old (Thiede and Eldholm, 1983), and their reconstructions show that the Denmark Strait did not exist as a seaway before 15-18 Ma. According to Bott (1983a), the Iceland-Faeroe Ridge was probably formed above sea level between 55 and $35 \mathrm{Ma}$ as a result of volcanic activity related to the Iceland hot spot, with the age of the crust younging toward Iceland. Based on Deep Sea Drilling Project (DSDP) Sites 336 and 352 , drilled on the flanks of the ridge, the subsidence is estimated at an average rate of $30 \mathrm{~m} / \mathrm{m}$.y., which is similar to other aseismic ridges (Nilsen, 1983). Thiede and Eldholm (1983) estimated that the main ridge platform did not sink below sea level before middle Miocene times, with the highest peaks of the ridge not being submerged before the Pliocene, whereas Wold et al. (1993) suggested a slightly different subsidence history, based on assumptions of reheating events of the lithosphere.

There are various views about the origin of the Faeroe Islands. Talwani and Eldholm (1972) proposed that the Faeroes were underlain by anomalous thick oceanic crust, whereas Bott (1983a), based on evidence of crustal velocities, plate tectonic reconstructions, and the lack of post-Paleocene subsidence of the islands, suggests that the Faeroes are underlain by continental crust with a major volcanic overprint.

Similar questions have been raised with respect to the origin of the underlying crust of the Faeroe-Shetland Channel (Fig. 10). It has been suggested that it is underlain by strongly rifted, thinned, and intruded continental crust, although a linear, intrusive complex in the axial opaque zone has been presumed to be related to seafloor spreading between the Faeroes and Scotland according to Ridd (1983). Mudge and Rashid (1987), however, exclude creation of oceanic crust under the Faeroe-Shetland Channel. They suggest that the area is underlain by stretched Precambrian metamorphic basement and that the observed igneous activity was restricted to widespread intrusion of sills and formation of igneous centers. They imply rifting in the area between Turonian and Maastrichtian times, with major depocenters of late Cretaceous and early Paleocene marine shales. During the late Paleocene, increasingly restricted marine conditions developed within the Faeroe Basin, which gradually was filled with a prograding sequence of coastal and deltaic sediments. Turner and Scrutton (1993) also document an abnormal acceleration in the basincenter subsidence in the late Paleocene, with simultaneous flank uplift, which they relate to the initiation of the Iceland plume and the development of a compressive, intraplate stress regime in mid-Paleocene. The top of the Paleocene sequence is defined by a regional unconformity that represents the emergence and erosion of part of the basin fill (Mudge and Rashid, 1987). Full marine conditions were not re-established before the early Eocene and the onset of normal, re- 

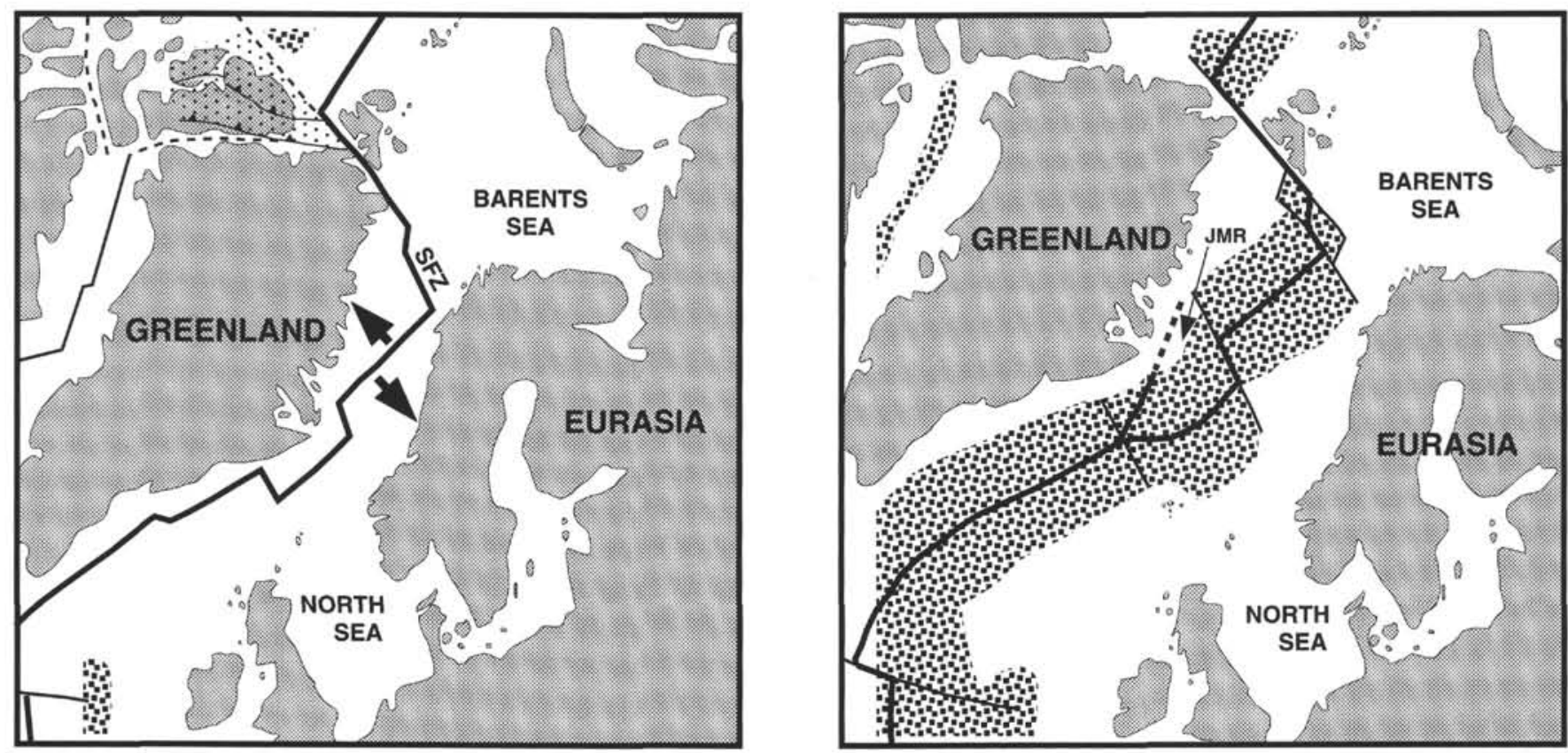

Figure 8. Schematic plate tectonic reconstructions to the time of breakup, pre-Anomaly 24B time (left), and to the time of change in relative plate motion near the Eocene-Oligocene transition, Anomaly 13 time (right) (Myhre et al., 1992). SFZ = Spitsbergen Fracture Zone, JMR = Jan Mayen Ridge.

gional tectonic subsidence is closely related to the onset of seafloor spreading to the northwest in the earliest Eocene (Turner and Scrutton, 1993).

The Wyville-Thomson Ridge at the northern end of the Rockall Trough (Fig. 10) separates the latter from the Faeroe-Shetland Channel and forms the easternmost, and least well understood, part of the Greenland-Scotland Ridge. The ridge forms a volcanic barrier between the Rockall Trough and Faeroe-Shetland Channel, and the time of subsidence of the ridge plays an important role in North Atlantic deep circulation. A better understanding of the age and nature of the ridge is needed before the subsidence pattern and paleobathymetry can be reconstructed with reasonable certainty. According to Boldreel and Andersen (1993), the Wyville-Thomson Ridge Complex has experienced at least three Eocene to Miocene compressional phases. The first during the late Paleocene-early Eocene, the second during the Oligocene, and the last during the middle or late Miocene.

\section{Fram Strait}

The northernmost Atlantic-Arctic Gateway, the Fram Strait, represents the only deep-water connection from the Arctic Ocean to the rest of the world's oceans. Therefore, to understand the plate tectonic evolution of this area is of critical importance with respect to the timing of water-mass exchange between the Norwegian-Greenland Sea and the Arctic Ocean.

Several suggestions have been made for the opening and initiation of a deep-water connection in the northern Greenland Sea through the Fram Strait area. The various models span from the early Oligocene, Anomaly 13 time, to the late Miocene, Anomaly 5 time (Crane et al., 1982; Eldholm et al., 1990; Kristoffersen, 1990a, 1990b; Lawver et al., 1990; Kutzbach et al., 1993; Myhre et al., 1995; see also reviews by Vogt, 1986a, 1986b).

The Fram Strait area is restricted to the south by the shallow aseismic Hovgård Ridge microcontinent (at about $1200 \mathrm{~m}$ below sea level $(\mathrm{mbsl}))$, while the present day sill depth north of the ridge is at 2600 $\mathrm{m}$, the Greenland-Spitsbergen Sill. The northern and eastern boundary of the Greenland-Spitsbergen Sill consists of the active plate boundary, the Spitsbergen transform system (Figs. 5 and 11). Seismic lines collected over the western part of the Yermak Plateau show sediments building out toward the active plate boundary and overflowing into the ridge axis and fracture zones. It has been suggested that the southern part of the Yermak Plateau is underlain by continental crust and that the northern part has a volcanic origin and was created together with the Morris Jesup Rise mainly between Anomaly 18 and 13 time (Feden et al., 1979), as a single subaerial feature extending across the southernmost part of the Eurasia Basin. Little is known about the subsidence history of both features, but, together with the oblique opening of the area between the Knipovich and Gakkel ridges, they probably had a major influence on the circulation pattern through most of the Miocene. The 700-m isobath defines the southern part of the Yermak Plateau at approximately $82^{\circ} \mathrm{N}$ while the $1000-\mathrm{m}$ isobath defines the plateau north of $82^{\circ} \mathrm{N}$.

It is important to know the westward extent of both the old Eocene volcanic crust of the northern Yermak Plateau and the continental crust farther south for plate tectonic reconstructions of the area, but so far no continent/ocean boundary along the southwestern edge of the Yermak Plateau has been identified. A similar problem exists for the conjugate part of the northeast Greenland margin. Furthermore, the complete lack of seafloor-spreading anomalies makes it very difficult to define the extent of oceanic crust in the Fram Strait area and the northeastern boundary of the Hovgård microcontinent. Morphologically, there is only a narrow passage from the Arctic Ocean, through the Lena Trough area (Eldholm et al., 1990; Fig. 11), toward the Spitsbergen Fracture Zone, which probably indicates a very limited extent of oceanic crust in that area.

Plate tectonic reconstructions by Lawver et al. (1990) and Kristoffersen $(1990 \mathrm{a}, 1990 \mathrm{~b})$ both show a quite late timing of the onset of deep-water circulation through the Fram Strait region. Lawver et al. (1990) suggest a shallow-water connection established between 15 and $10 \mathrm{Ma}$, while the deep-water connection was probably not established before 7.5 to $5 \mathrm{Ma}$. What Lawver et al. (1990) and Kristoffersen (1990a, 1990b) did not include in their models is the influence, extent, and subsidence through time of the Hovgård microcontinent, which probably acted as a considerable plug in the southern part of Fram Strait through large parts of the Miocene (Myhre et al., 1995). 


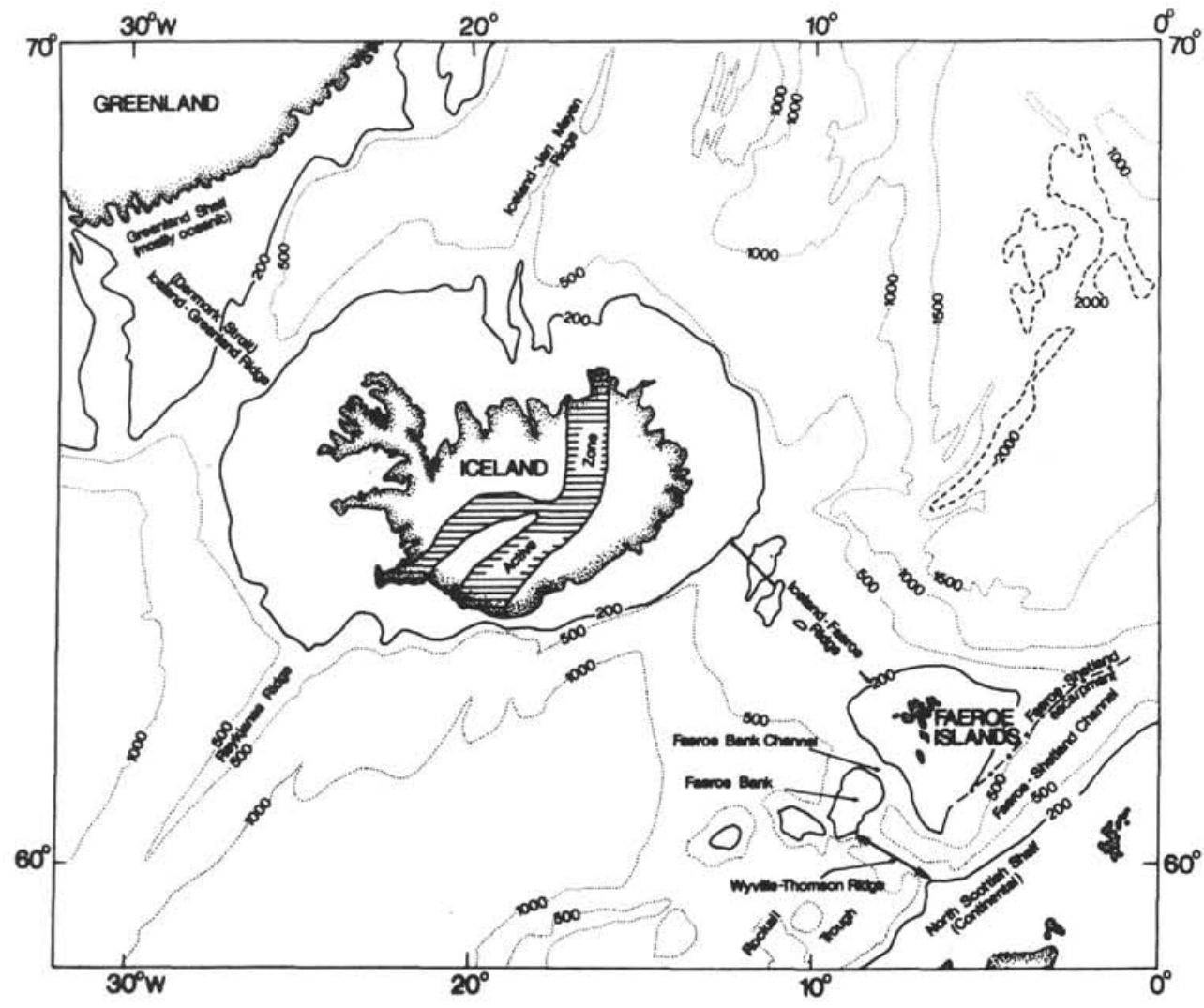

Figure 9. The morphology of the Greenland-Scotland Ridge showing the major features (Bott, 1983b).

\section{MODERN OCEANOGRAPHY}

Despite the small size of the Norwegian-Greenland Sea and of the Arctic Ocean, the modern oceanographic situation in these high-latitude Northern Hemisphere deep-sea basins is of utmost importance for the oceanography of the world ocean as well as for the climate over the Northern Hemisphere, including the deflection of the temperate climatic zones over northwestern Europe. The complicated oceanographic situation, as well as the importance of the two gateways from the main North Atlantic Basin to the Norwegian-Greenland Sea (Greenland-Scotland Ridge) and between the NorwegianGreenland Sea and the Arctic Ocean (Fram Strait), is well illustrated in the two schematic figures produced by Aagaard and his colleagues (Aagaard and Carmack, 1994; Aagaard et al., 1985; cf. also Fig. 12).

The surface circulation in the Norwegian-Greenland Sea is dominated in its eastern part by imported temperate and saline Atlantic waters across the Greenland-Scotland Ridge, and in its western part by the export of brackish, cold, partly ice-covered waters of the East Greenland Current, which reach the western North Atlantic Ocean through the Denmark Strait. The temperate Atlantic waters enter the Norwegian-Greenland Sea as part of the North Atlantic drift system. They continue their path along the Norwegian continental margin (here called the Norwegian Current) and are separated from the Norwegian coast by the Norwegian Coastal Current system (Sætre and Mork, 1981). To the north of the Fennoscandian peninsula they subdivide into a branch that turns east, keeping the Kola Peninsula permanently ice-free, and a branch which follows the Barents Sea continental margin to the north until it reaches Fram Strait and dips below the Arctic sea-ice cover. The import of Atlantic waters is balanced by the outflow of the cold East Greenland Current, which trails the East Greenland continental margin until it reaches Denmark Strait and the northwest Atlantic Ocean. Major convective gyres develop in the Norwegian Current system adjacent to the Vøring Plateau, and in the
East Greenland Current system, both in the area to the south of Fram Strait as well as over the Iceland Plateau. From there, a very complicated system of fronts separates the Norwegian Current waters from the central "polar" water masses of the central Norwegian-Greenland Sea, and again separates the latter from the waters of the East Greenland Current. However, it is quite clear that steep oceanographic gradients separate the eastern and western Norwegian-Greenland Sea. Some of the major oceanographic fronts are prominent features that control both the subdivision into surface current systems and the habitats of the major plankton communities.

The complicated details of the circulation pattern between these water masses can be illustrated by means of a satellite image covering Fram Strait (Fig. 13), where the highly turbulent water masses of the West Spitsbergen Current can be seen in the east, and the drifting seaice cover and turbulent eastern boundary of the East Greenland Current can be observed in the west. The fact that the West Spitsbergen Current reaches the area just north of Svalbard, keeping part of the Yermak Plateau ice-free, was of major importance for Leg 151 because the JOIDES Resolution was able to enter these waters to drill sites both in the central Fram Strait as well as to the north of Svalbard. These water masses also have their distinctive hydrographic properties with a wide range of temperatures as well as salinities (Fig. 12A). Historic investigations (Lamb, 1972) have shown that the boundaries between these surface water masses are subject to large spatial changes, as is illustrated by the data set collected for the Little Ice Age (cf. Myhre and Thiede, 1995).

The complicated nature of the stratification of water masses in the deep Arctic Ocean (Aagaard and Carmack, 1994) and the Norwegian-Greenland Sea (Koltermann, 1987), as well as the processes of their renewal, are even more complicated. Dense, cold, and saline surface waters are produced in the open ocean basins, in particular in the Greenland Basin and over the Iceland Plateau, until they penetrate the density stratification of the Norwegian-Greenland Sea and down- 


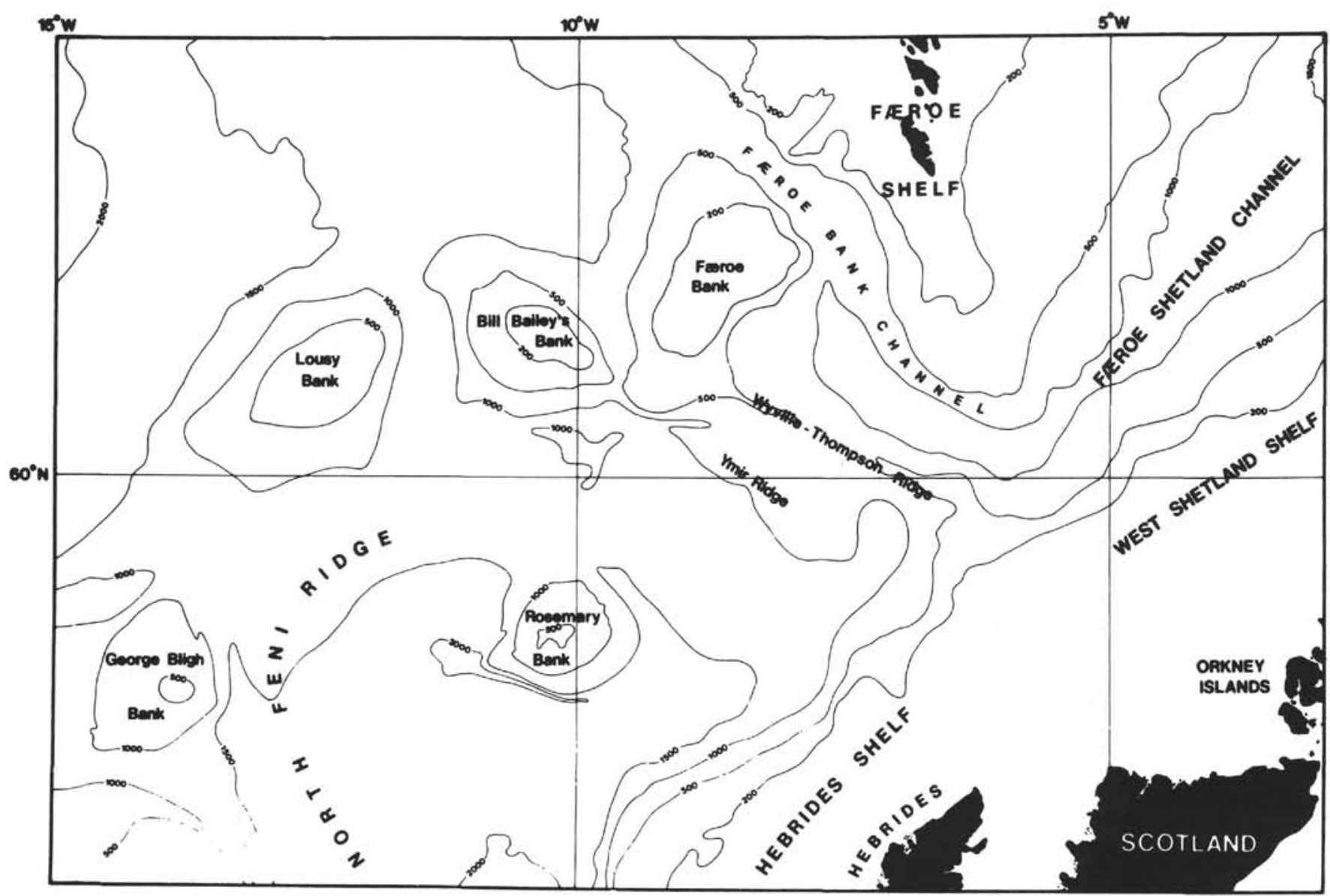

Figure 10. Major bathymetric structures south and east of the Faeroe Islands (Roberts et al., 1983).

well into intermediate and deep layers of the sub-basin (Aagaard et al., 1985; well illustrated in Fig. 12A). The generation of sea-ice over the shelf seas produces dense, salty brines that flow across the shelf break into the adjacent deep-sea basins and are advected to the intermediate and deep waters of the deep basins according to their density properties. Schlosser et al. (1991), using hydrographic observations and measurements of the concentration of chlorofluorocarbons, were able to show that the formation and renewal of the Greenland Sea deep water is subject to major quantitative fluctuations; in 1980 a major slowdown was observed in the Norwegian-Greenland Sea. This must have consequences for the export of intermediate waters from the Norwegian-Greenland Sea, across the Greenland-Scotland Ridge, into the deep North Atlantic Ocean.

Therefore, both the data describing the variability of the location of the various fronts between the major surface water masses, as well as the pattern of renewal and formation of the deep waters, demonstrate that the oceanographic system in the Norwegian-Greenland Sea, as well as in the adjacent Fram Strait-Arctic Ocean area, are subject to rapid change and major fluctuations with an important impact on both the hydrography of the world ocean as well as the climate over the Northern Hemisphere. In Figure 14 we have taken one of the Marginal Ice Zone Experiment (MIZEX) summer situations illustrating extent of sea ice and surface temperatures, and plotted the locations of Leg 151 drill sites onto it. The geological data that allow the reconstruction of the paleoceanographic scenarios of the NorwegianGreenland Sea and the adjacent North Atlantic Ocean, however, demonstrate that the late Holocene fluctuations are minor when compared to the large changes this region has experienced during the late Tertiary and entire Quaternary, in the course of climatic fluctuations caused by the change from the pre-glacial to the glacial stage as well as the alternations between glacials and interglacials.

\section{CENOZOIC PALEOCEANOGRAPHY \\ Tertiary}

According to the results from previous ODP and DSDP drilling in the Norwegian-Greenland Sea, the paleoceanographic history of this young ocean can be subdivided into a number of major chapters.

\section{Eocene to Early Miocene}

The Norwegian-Greenland Sea was definitely ice-free and filled with fertile temperate waters, as indicated by the rich siliceous faunas and floras as well as by the high accumulation rates of siliceous material. During the early part of its history, the Norwegian-Greenland Sea consisted of a rather narrow band of isolated subbasins that did not have a wide and deep connection to the North Atlantic Ocean or to the Arctic Ocean proper (Vogt et al., 1981). The sediments are not intensely burrowed but rather laminated or intensely stratified, which can be taken as a sign of isolation of the intermediate and deep water masses and potentially of oxygen deficiency.

\section{Middle to Late Miocene}

The proportion of terrigenous components in the sediment increased in middle to upper Miocene deposits, which consist mainly of laminated clay and sandy muds with decreasing amounts of bio- 


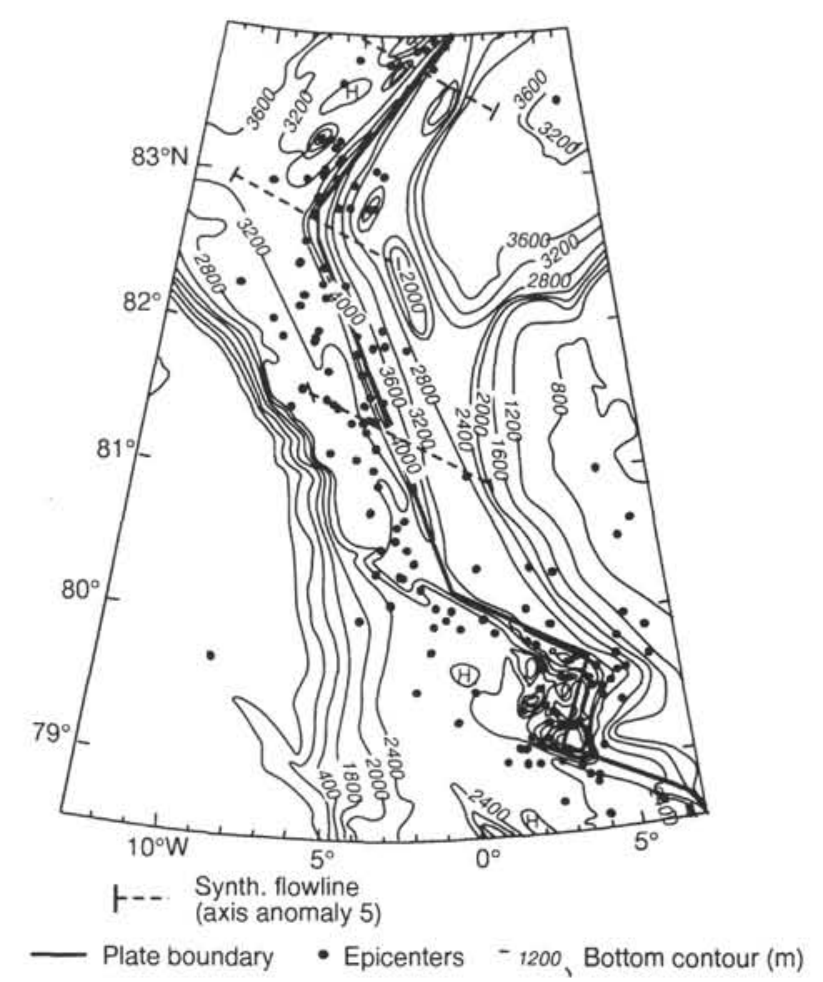

Figure 11. The plate boundary region (Spitsbergen Transform between Knipovich and Gakkel ridges [Eldholm et al., 1990]).

genic components. The first appearance of coarse to rich ice-rafted debris (IRD) is observed in Upper Miocene sediments, suggesting the early glaciation of some of the continents or islands adjacent to the Norwegian-Greenland Sea (probably Greenland, cf. Wolf and Thiede, 1991).

\section{Pliocene}

Throughout the entire investigated area, Pliocene deposits are characterized by the influence of cold surface waters and the influx of IRD to the sites on the Iceland Plateau, off East Greenland, in Fram Strait, and on the Yermak Plateau. A particularly disturbing disagreement existed between the observations on northeastern Greenland (Funder et al., 1985), where plant remains indicated the existence of boreal forests during a stratigraphically well-defined interval of the Pliocene, for which the oceanic counterpart was lacking. However, detailed stratigraphic and paleontological investigations of the Fram Strait and Yermak Plateau sites now (cf. paper on planktonic foraminifers by Spiegler, this volume) give evidence for the existence of rather warm water masses, which were inhabited by planktonic foraminifers today found in lower latitudes. From this point, there seems to be an agreement between the oceanic and the terrestrial record. In the course of the Pliocene (earlier off Greenland, later off northwestern Europe and Svalbard), an important intensification of the ice-rafting has been observed, which seems to relate to the dynamics of the ice sheets at the outskirts of the Norwegian-Greenland Sea.

\section{Quaternary}

The Quaternary deposits that were recovered at all Leg 151 sites are dominated by silty clays and muds (all recoveries were very good, with the exception of Site 913 off eastern Greenland, where frequent dropstones prevented a recovery of sufficient quality to make de- tailed stratigraphic statements on the uppermost part of the sedimentary column). The Quaternary sediments are characterized in the entire area by intense fluctuations between glacial and interglacial deposits. However, the glacial and interglacial deposits are of a highly variable nature, which makes it quite difficult to correlate drill sites from the eastern and western side of the Norwegian-Greenland Sea to the northernmost records drilled in Fram Strait and on the Yermak Plateau. Lithologies of the ice-rafted material relate to the ice sheet on Greenland as well as to northwestern European ice sheets, and allow through their stratigraphy some very detailed observations on the temporal variability and dynamics of the individual ice sheets.

\section{PREVIOUS HIGH-LATITUDE NORTHERN HEMISPHERE DSDP AND ODP DRILLING}

A history of scientific drilling in the Northern Hemisphere polar and subpolar deep-sea basins for studying the Cenozoic paleoenvironment and paleoclimate would not be complete without a brief excursion to the North Pacific. Legs 18 and 19 (Kulm, von Huene, et al., 1973; Creager, Scholl, et al., 1973) were part of the very early DSDP activities. They visited the northern rim of the Pacific Ocean and Bering Sea, providing some important data on the onset of Northern Hemisphere Cenozoic glaciation in an area geographically opposite to the ODP Leg 151 drill sites. Most recently, this area was revisited by ODP Leg 145 (Rea, Basov, Scholl, and Allan, 1995), resampling the northernmost North Pacific but not entering the Bering Sea.

Leg 18 sampled the North Pacific and found glacio-marine deposits in Sites 178-182 (Alaska Abyssal Plain, Aleutian Trench, and continental margin off southwest Alaska). The oldest record of icerafted erratics has been observed in the glacio-marine deposits of the Alaska Abyssal Plain, where upper Pliocene and Pleistocene deposits with erratics down to $258 \mathrm{~m}$ below seafloor ( $\mathrm{mbsf}$ ) can be subdivided into three lithologic units, each with variable amounts of erratics and henceforth documenting a pattern of temporal variability of ice-rafting. DSDP Leg 19 continued the program of Leg 18 toward the west, but it also crossed over the Aleutian Island chain into the deep Bering Sea. As did Leg 18, it stayed in relatively low latitudes (south of $57^{\circ} \mathrm{N}$ ) and the drill sites therefore are not well placed to address the onset and evolution of Cenozoic Northern Hemisphere glaciations. The potential to make pertinent observations was further reduced by the fact that these early legs only did spot rotary-coring, obtaining an incomplete and highly disturbed record of the youngest parts of the sedimentary sequences. However, evidence for ice-rafting with variable intensity has been found in sediments possibly as old as early Pliocene (Site 187) and in the upper Pliocene to Quaternary deposits at most of the drill sites. No attempts have been made to quantify icerafting or to determine potential provenances of the erratics. Leg 145 (Rea, Basov, Janecek, Palmer-Julson, et al., 1993; Rea, Basov, Scholl, and Allan, 1995) sampled locations just to the south of the western end of the Aleutians and in the northern Gulf of Alaska. The ice-rafted material indicates an onset of glaciation on this side of the Northern Hemisphere well back into the Miocene, when ice-rafted material from the Kamchatka peninsula could be observed in the adjacent deep-sea basins. As in the Norwegian-Greenland Sea/Fram Strait area, the middle Pleistocene deposits are characterized by a relatively warm spell that interrupted the high-latitude cooling for about a million years, after which the glacial history of the Northern Hemisphere continued with renewed vigor.

DSDP visited the North Atlantic several times, but only once the Norwegian-Greenland Sea (Talwani, Udintsev, et al., 1976) during Leg 38. Spot- and rotary-coring and mostly geophysical and tectonic objectives did not provide an opportunity to decipher much of the detail of the late Cenozoic paleoenvironmental history, which was later defined with respect to onset and variability of Northern Hemisphere glaciations in North Atlantic drill sites south of the Greenland-Scot- 
A

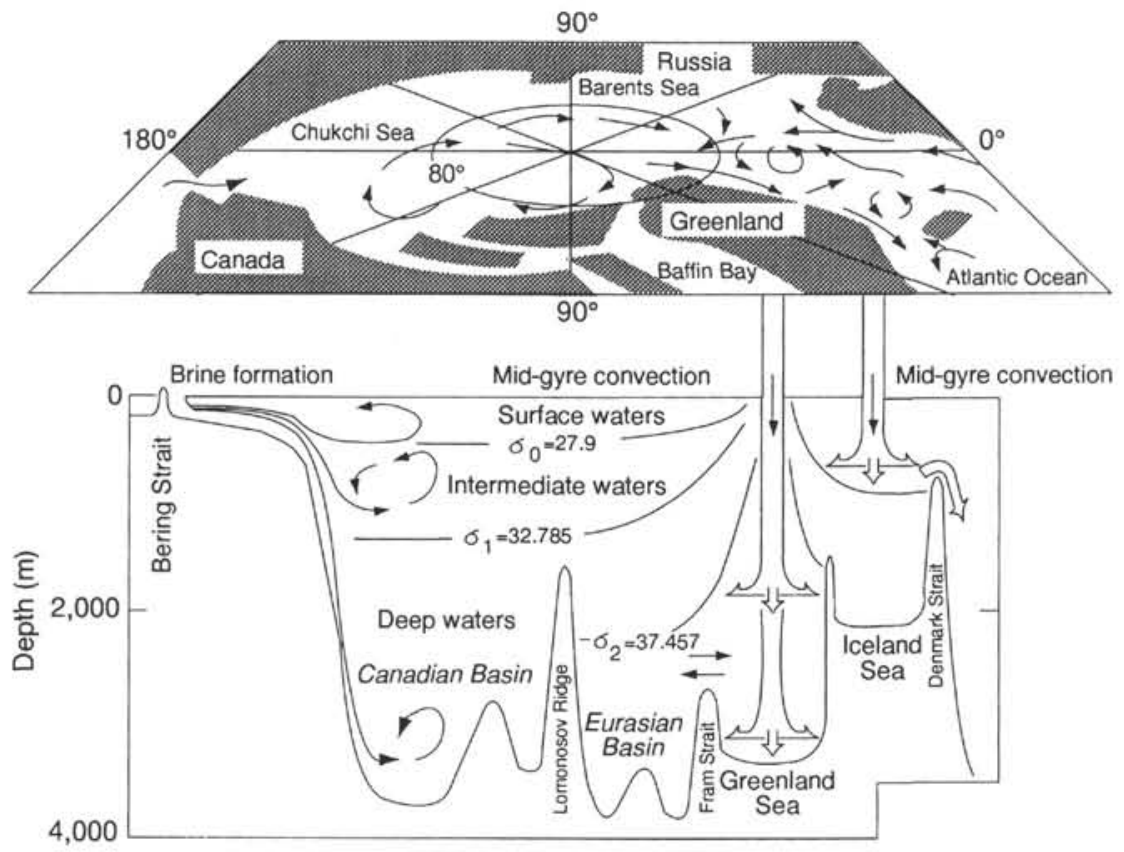

B

RADLATION BALANCE

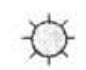

PRECIPITATON FROM MID LATIUDE STORMS

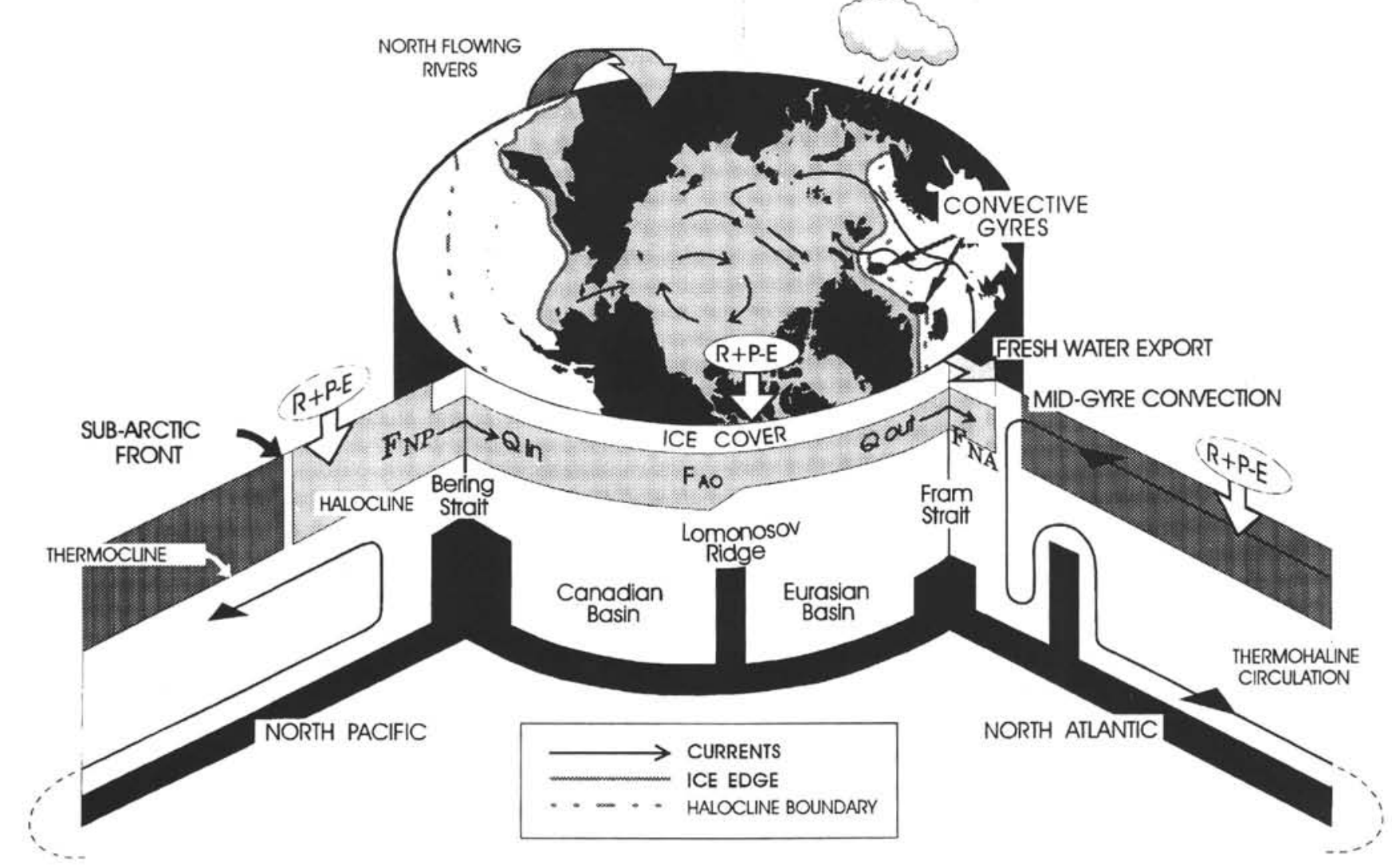

Figure 12. A. Schematic circulation and water-mass structure in the Arctic Ocean and Norwegian-Greenland Sea (Aagaard et al., 1985). B. Schematic Arctic Ocean climate connections (Aagaard and Carmack, 1994). 


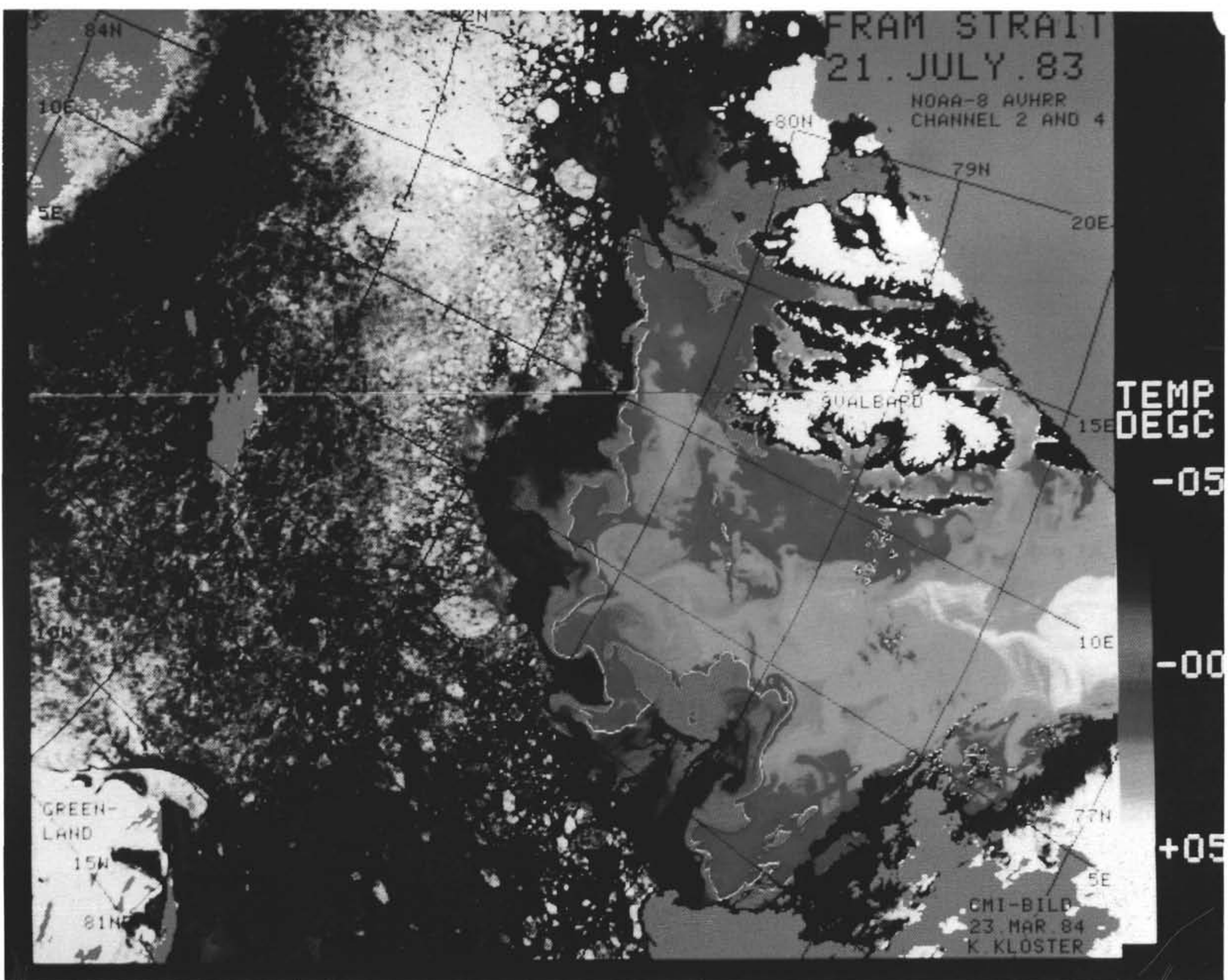

Figure 13. Satellite image from the Advanced Very High Resolution Radiometer on the NOAA-8 satellite, 21 July 1983 . The image is composed of channel 2 (visual), which shows the sea ice in gray-scale from white to black, and channel 4 (infrared), which shows the surface temperature of ice-free water in colors (from $-1^{\circ} \mathrm{C}$ to about $+5^{\circ} \mathrm{C}$ ). The West Spitsbergen Current is seen in colors (white-yellow and red) as far north as $80^{\circ} 30^{\circ} \mathrm{N}$. The violet areas are clouds (image courtesy of Nansen Environmental and Remote Sensing Center). 

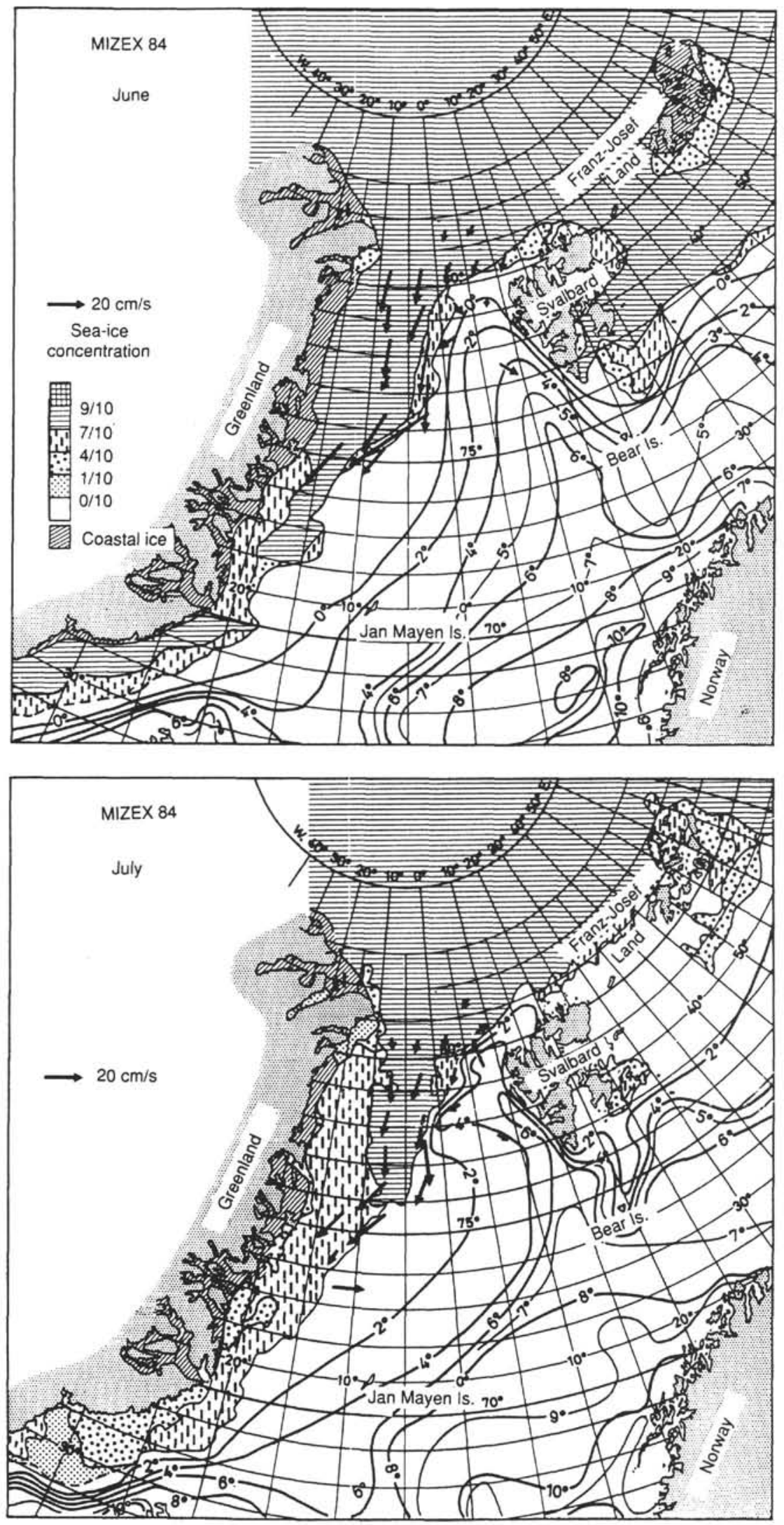

Figure 14. Oceanography and ice cover of the modern Norwegian-Greenland Sea and Fram Strait (Gascard et al., 1988). 
land Ridge (Shackleton et al., 1984). Many of the Norwegian-Greenland Sea drill sites contained ice-rafted debris (both erratics and Cretaceous Inoceramus prisms are mentioned); their stratigraphic distribution confirmed that sea-ice cover and ice-rafting were not restricted to the Quaternary but, while exhibiting considerable temporal variation, extended clearly into the Tertiary, at that time Pliocene. Warnke and Hansen (1977), based on the Leg 38 material, later confirmed this and also established a regional distribution of icerafting with maxima along the Greenland and Norwegian continental margins.

ODP Legs 104 and 105 were the next major contribution toward deciphering the history of Northern Hemisphere Cenozoic cooling and glaciation. Leg 105 (Srivastava, Arthur, Clement, et al., 1987; 1989) visited the Labrador Sea and Baffin Bay area where relatively old Cenozoic glaciation could be established. Detailed investigations of the record of ice-rafting at Site 646 (Labrador Sea to the South of Greenland) revealed a late Middle Miocene onset of glaciation (Wolf and Thiede, 1991), probably in southern Greenland.

The major scientific objective of the Leg 104 central drilling location on the Vøring Plateau off mid-Norway was oriented toward sampling a thick, dipping-reflector sequence of volcanic origin (Eldholm, Thiede, Taylor, et al., 1987), related to the initial opening of the Norwegian-Greenland Sea (Hinz et al., 1993; Eldholm, 1991; Eldholm and Thomas, 1993). However, together with additional drill sites on either side along a transect across the Vøring continental margin, this site also revealed important data about the history of the Norwegian Current and the onset of Northern Hemisphere Cenozoic glaciations. The most important observations (Eldholm, Thiede, Taylor, et al., 1989; Thiede et al., 1989) on paleoenvironmental evolution were the following:

1. Even though the stratigraphy of Leg 104 Sites 643 and 642 is incomplete because of the occurrence of several, poorly defined hiatuses, there is no question that both sites have sampled intervals documenting the arrival of the first eastern Norwegian-Greenland Sea ice covers. Pre-glacial conditions provided favorable habitats for rich siliceous and calcareous plankton communities with excellent sediment records preserved in the Miocene and Pliocene.

2. A major revolution of the deep-water habitats and hydrographies in the eastern Norwegian Sea is suggested by the invasion of calcareous benthic foraminifers $\sim 13.5 \mathrm{Ma}$, when the first, probably ice-rafted, sediment components are observed at DSDP Site 341.

3. Calcareous pelagic microfossils occur sporadically in upper Miocene to Quaternary sediments. In many instances, in particular in the Quaternary, their occurrence is controlled by dissolution. It is only during the last $1 \mathrm{~m} . \mathrm{y}$. that their frequency follows an increasing trend.

4. Unlike the area south of the Greenland-Scotland Ridge, where indicators for glaciation are observed only as late as $2.4 \mathrm{Ma}$ (Shackleton et al., 1984), they appear over the Vøring Plateau, at least intermittently and first in relatively small quantities, since late Miocene times. In the Labrador Sea small amounts of ice-rafted terrigenous debris have been found as deep as upper middle Miocene sediments (Wolf and Thiede, 1991).

5. At $2.5-2.8 \mathrm{Ma}$, the abundance of ice-rafted terrigenous debris suddenly increases, suggesting a dramatic intensification of glaciation. A similar development can be observed south of Greenland (ODP Site 646; Wolf and Thiede, 1991), only the intensification occurred at $\sim 4 \mathrm{Ma}$.

6. Since that time, more than 26 severe glacial events have affected the eastern Norwegian Sea, supporting the notion that the Northern Hemisphere ice cover is unstable, reacting to a highly dynamic climate system.
7. At the same time, evidence for interglacial periods is a rare exception in the Leg 104 sediments, suggesting that interglacials have been short and that the dominant mode of the depositional environment of the eastern Norwegian Sea has been a glacial one.

8. Dropstones can sometimes be related to their source regions in Scandinavia, Greenland, and the North Sea area. Their distributions vary considerably with time, indicating major changes in the spatial distribution and dynamics of the large circumArctic continental ice sheets.

9. Glacial-interglacial changes exhibit cyclical variations related to the Milankovitch frequencies, which are documented by a wide variety of sediment properties, thereby providing a medium for dating the historic climate record as a basis for climate prediction.

\section{THE NORTH ATLANTIC-ARCTIC GATEWAYS PROGRAM OF ODP (LEGS 151 AND 162) Scientific Perspectives}

The Norwegian-Greenland Sea and adjacent deep-sea basins are characterized by strong latitudinal gradients in the sea-surface environment and also by unusually strong meridional gradients caused by the warm Atlantic influence in the east and the cold polar influence in the west (Fig. 2). Intense seasonal variability is also a prominent feature of the surface environments, resulting in strong and rapidly migrating ocean fronts. The origin and subsequent variability of these fronts are almost totally unknown. Apart from the data obtained from the Norwegian margin by Leg 104, no high-quality samples existed older than a few hundred thousand years. Thus, to derive a comprehensive understanding of the whole ocean-climate system of this area, and its modus operandi in a global-perspective critical system, it is necessary to obtain continuous sediment cores at a variety of locations that can document changes of the sea-surface environments and the underlying causes for these changes through late Paleogene, Neogene, and Quaternary times.

No scientific drilling has so far been performed in the Arctic, and, due to its inaccessibility, very limited material is available from conventional coring (Thiede and NAD Science Committee, 1992). Sediment cores from the areas north of $76^{\circ} \mathrm{N}$, where DSDP Site 344 is located, represent less than $10 \%$ of the last 70 m.y., implying that virtually no information exists of the paleoceanography of the Arctic Ocean. This stands in distinct contrast to the fundamental oceanographic and climatic influence of this ocean. Although the ice cover prevents the JOIDES Resolution from entering most parts of the Arctic Ocean (Figs. 13, 14), areas on the Yermak Plateau north of Svalbard, and hence north of the gateway (Fram Strait) between the Norwegian-Greenland seas and the Arctic Ocean, are ice-free and accessible in late summer during normal ice years and can potentially be drilled by normal ODP methods.

Following recommendations defined after Leg 104 (Thiede et al., 1989) and further specified by the NAAG Detailed Planning Group (DPG) (Ruddiman et al., 1991), Leg 151 was scheduled to drill a series of sites (Fig. 3) in several geographically remote, partly ice-covered locations (the northern gateway region, i.e., Yermak Plateau and Fram Strait, the East Greenland Margin, and the Greenland-Norway Transect: the Iceland Plateau and the Greenland-Scotland Ridge) with the aim of reconstructing the temporal and spatial variability of the oceanic heat budget and the record of variability in the chemical composition of the ocean. Leg 151 was also to undertake a study of circulation patterns in a pre-glacial, relatively warm, polar and subpolar ocean, and the mechanisms of climatic change in a predominantly ice-free climatic system. In addition, the proposed drilling included a collection of sequences containing records of biogenic fluxes $\left(\mathrm{CaCO}_{3}\right.$, opal, and organic carbon) and stable-isotopic carbon and 
oxygen records, which addressed aspects of facies evolution and depositional environments as well as the carbon cycle and productivity. The drilling approach focused on rapidly deposited sediment sequences to be used for high-resolution, Milankovitch-scale paleoclimatic analysis and rapid sub-Milankovitch-scale climate changes.

Most of the proposed sites were arrayed as either broad northsouth and east-west transects to monitor spatial paleoclimatic variability or closely spaced suites of cores across a range of depths to monitor vertical variability. Other approaches included choosing sites for deep drilling that will better constrain the time of opening of Fram Strait and placing sites in order to monitor downstream sedimentological effects of deep flow through narrow gateway constrictions.

In addition to the paleoenvironmental objectives, a couple of sites, in particular in the Fram Strait and Yermak Plateau area, addressed the age and nature of basement rocks. The sites to the north of Svalbard also constituted the first scientific drilling to be conducted in the Arctic Ocean proper, thereby representing one of the first steps of the Nansen Arctic Drilling Program (Thiede and NAD Science Committee, 1992).

Leg 162 was conducted during the late summer of 1995 and represents an important supplement of the Leg 151 drill sites. In addition, studies of the paleoenvironmental history of the western Norwegian-Greenland Sea must also consider results of Legs 152 and 163 , which were both carried out to the south of Denmark Strait southeast of Greenland (Larsen et al., 1994; Duncan, Larsen, Allan, et al., in press). The sites of Leg 162 (Jansen, Raymo, Blum, et al., 1996) are clustered on both sides of the Greenland-Scotland Ridge with one exception, Site 968, which drilled one of the trough-mouth fans of Svalbard in the southern part of Fram Strait. The drill sites concentrated dominantly on the Neogene and Quaternary sediment record. Beautiful high-resolution stratigraphic sections were recovered that will allow us to amplify our knowledge of the short-term climatic variations controlling the paleoceanography of the Norwegian-Greenland Sea and the adjacent deep-sea basin of the North Atlantic Ocean. Because the detailed results of Leg 162 will be published in a later volume, these data will not be dealt with here except in a very superficial way.

Following the recommendations of the NAAG DPG and of the individual drill-site proposals, the scientific objectives of ODP Leg 151 can be summarized under the following themes (Ruddiman et al., 1991):

1. Cenozoic paleoceanography of the Nordic Seas;

2. Cenozoic evolution of climate in high northern latitudes;

3. Oceanic sediment budgets in response to paleoceanographic changes in the Nordic Seas;

4. Surface water-mass evolution in the Nordic Seas;

5. Temporal and spatial variation of sea-ice distribution;

6. The gateway problem;

7. Deep water-mass evolution in the Nordic Seas; and

8. History of mountain glaciers and circum-Arctic continental ice sheets.

\section{Leg 151 Drilling Strategy}

Most of Leg 151's objectives required drilling long sequences of rapidly deposited ( $>20 \mathrm{~m} / \mathrm{m}$.y.) sediments. This approach permits retrieval of continuous sections for high-resolution analysis of the higher frequency (orbital-scale or higher) variations of the climate system. At the same time, it provides sequences spanning millions of years during which the long-term baseline climatic state may evolve toward generally colder conditions, as may the spectral character of orbital-scale variations.

Leg 151 comprises a series of sites proposed to form a north-south transect, an east-west transect (linked to Leg 104 sites in the east), and a bathymetric transect. The sites were proposed to be double, or even triple, APC/XCB cored in order to achieve $100 \%$ recoveries. The north-south transect extends from the Arctic Ocean (the Yermak
Plateau) via the Fram Strait and the Greenland and Iceland Seas into the northwestern North Atlantic. It can thereby tie into existing North Atlantic (DSDP Legs 81, 94) and Labrador Sea (ODP Leg 105) highresolution stratigraphies. This transect covers the major ocean basins of the region, provides sites on both sides of the Fram Strait and of the Greenland-Scotland Ridge, and addresses the evolution of northsouth environmental gradients from the Arctic to the North Atlantic.

The east-west transect uses the Leg 104 sites on the Vøring Plateau as its eastern tie-point and extends across to the area immediately off east Greenland. The main intention of this transect is to sample the strong environmental gradient between the polar regions off east Greenland and the temperate Atlantic waters off Norway, to study the inception and evolution of the strong middle- to high-latitude eastwest gradients and oceanic fronts, and to investigate differences in the oceanic and glacial evolution between Greenland and northern Europe. Additionally, it was necessary to include a central sample point along this transect in order to obtain clean pelagic records from the central parts of the basin.

Two bathymetric transects were also proposed to study sediment budgets, lysocline/CCD variability, and bathymetric gradients in ocean chemistry: one on the Yermak Plateau in the Arctic and the other on the slope between the Iceland Plateau and the Ægir Ridge (extinct spreading axis) in Norway Basin. This area is centrally located in the Norwegian-Greenland Sea and is not influenced by continental margin effects.

The overall drilling strategy was affected by (1) the priority of the proposed drill sites, (2) the availability of ice-breaker coverage, and (3) ice conditions. The following specific aspects apply to areas and sites chosen for Leg 151 (Figs. 3, 15).

\section{Yermak Plateau: Sites 910, 911, 912}

The Yermak Plateau is a topographic marginal high due north of Svalbard. The Morris Jesup Rise and northeastern Yermak Plateau are a pair of plateaus rising to crestal depths of 0.5 to $1 \mathrm{~km}$, which apparently were formed during the Eocene by excess Iceland-like volcanism along the southwestern Gakkel Ridge. The southern part of the Yermak Plateau may be thinned continental crust (Jackson et al., 1984). Thick sediment drapes both the western and eastern flanks. Gravity and piston cores show that the present sediment cover contains some biogenic calcareous components and documents normal pelagic sedimentation rates.

Drilling in this area enabled a study of environmental responses pre- and post-dating the opening of the deep gateway into the Arctic. It documents the timing of this event, the physical and chemical nature of the water masses associated with the gateway opening, and its influence on ocean circulation and climate. Furthermore, it provides a check for the theory linking this event with changes in the relative plate motions starting at about Anomaly 13 time, and the possible global impacts of the establishment of a deep connection between the Arctic Ocean and the world ocean. The other main achievement from drilling this area is that it provides a continuous upper Neogene record from the Arctic Ocean of the same quality as is available from lower latitude areas. This makes possible the identification of the onset of permanent ice cover in the Arctic and the magnitude of glaciation and ice sheets in the Arctic areas by identifying the onset and variation of IRD input into the Arctic Ocean. It should further enable studies of Milankovitch cyclicity in Arctic Ocean climates and circulation and how this cyclicity has evolved with time.

The area forms the northernmost end-member of a north-south transect of drill sites that ties into the other oceans. This is the first scientific drilling in any part of the Arctic. It will be the northernmost control point for stratigraphic/chronostratigraphic studies, a reference area for Arctic studies, and a northern tie-point for studies of the evolution of global thermal gradients. A series of sites in this region was proposed for three reasons: (1) the necessity for drilling more than one site to recover a complete stratigraphic section covering the time period of interest; (2) since the area lies in the marginal ice zone, 

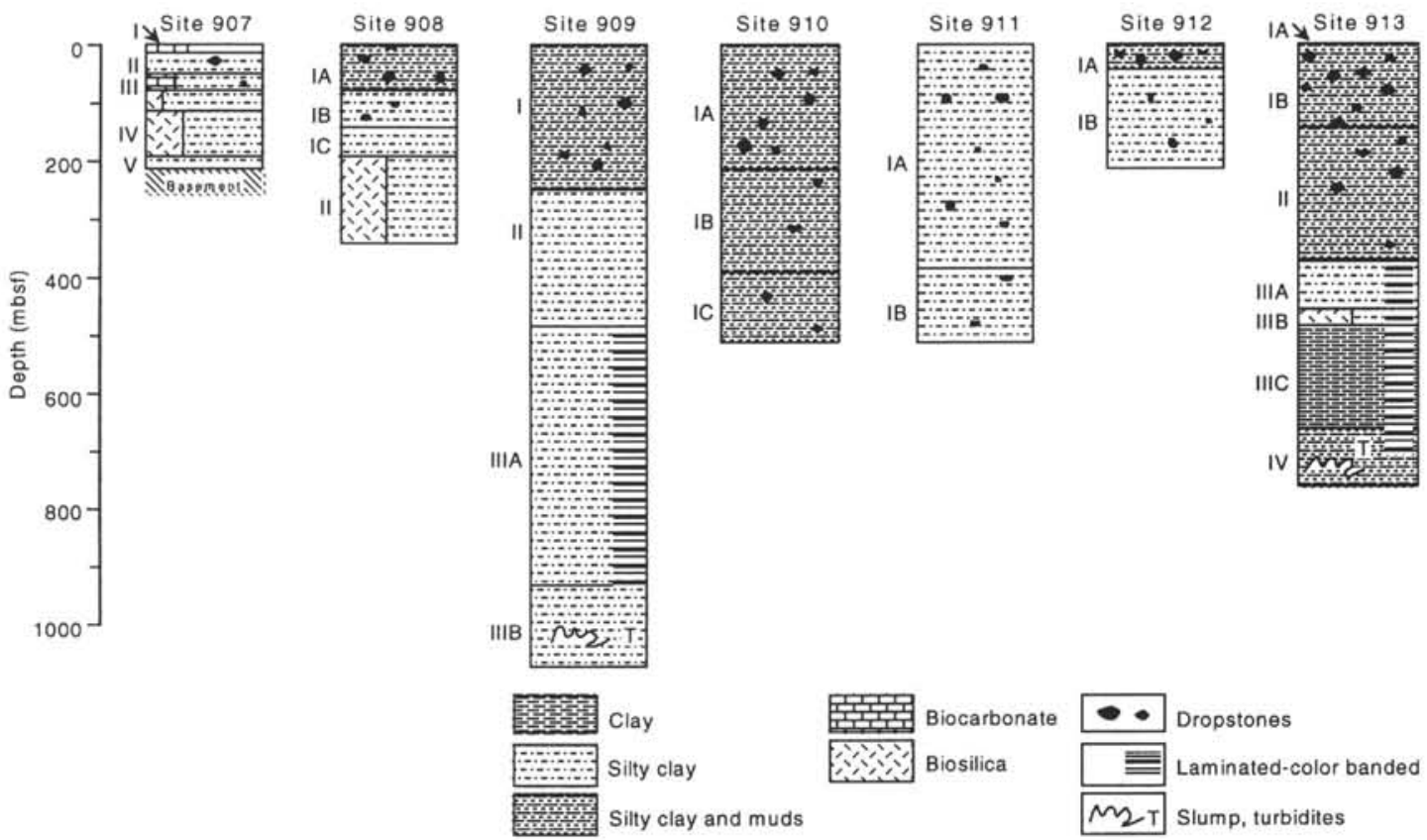

Figure 15. Drilling record of Leg 151 (Myhre, Thiede, Firth, et al., 1995).

and the northern and western sites especially are accessible only during favorable ice years, it is necessary to have a series of proposed sites to choose from, should one of them not be accessible; and (3) it is desirable to obtain a bathymetric transect of sites in the Arctic to monitor depth gradients in sediment-accumulation and water-mass properties.

\section{Fram Strait: Sites 908 and 909}

Site 909 is located in the Fram Strait, on a gentle elevated area northeast of the Hovgård Ridge. The site was designed to document the timing of the opening of a deep passageway through the Fram Strait and the history of deep- and shallow-water exchange between the Arctic and the world ocean. It also provides records of the onset and evolution of Arctic glacial history and the climatic variability of the Arctic region. The sites are located west of the complex spreading center, on post-Anomaly 13 crust. Multichannel seismic (MCS) and $3.5-\mathrm{kHz}$ lines document a gently draped sediment cover. The area is elevated with respect to the surrounding regions and should be protected against turbidites and slumps originating from the continental margins. A number of piston cores from this area document normal pelagic sedimentation rates and pelagic sediments with good isotopic and biostratigraphic age control for the Quaternary.

Site 908 is situated on the crest of the Hovgård Ridge. It was proposed in order to (1) determine the age and lithology of the sedimentary processes immediately postdating the opening of the Fram Strait, and (2) investigate the water-mass exchange in and out of the Arctic Ocean. The Hovgård Ridge is a topographic high that is thought to be a continental fragment severed off Svalbard during the early rifting phase (Eldholm and Myhre, 1977; Myhre and Eldholm, 1988). A few small sediment basins located on the ridge potentially contain sediments documenting the early history of sedimentation after the ridge subsided below sea level.

\section{East Greenland Margin: Site 913}

The site on the East Greenland Margin is located on a north-south transect paralleling the path of the East Greenland Current (EGC).
The objectives were to date the onset of the EGC, monitor deep-water formation and surface-water paleoenvironments in the Greenland Sea, determine their influence on the variability of the polar front and on the Northern Hemisphere paleoclimate, decipher the evolution of the Greenland Ice Sheet, monitor contour-current activity and sediment-drift deposition in the Greenland Basin, and study Paleogene paleoceanography. The extensive work farther north prevented us from drilling any of the other EGM sites (Ruddiman et al., 1991).

\section{Iceland Plateau: Site 907}

The sites proposed for this area composed a bathymetric transect of three sites as well as a site in the central Iceland Sea designated to be a part of the east-west transect. Of the proposed sites, we were only able to drill Site 907 .

Site 907 represents the mid-point in the east-west transect in the southern Nordic Seas, and was proposed to (1) monitor the history of oceanic and climatic fronts moving east and west across the Iceland Plateau, (2) derive an open-ocean record of IRD and carbonate, and (3) determine the history of the formation of northern-source deep waters. As mentioned above, the Leg 104 sites, being located close to the Norwegian continental margin, suggest local influence on the IRD records and possible increased dissolution and dilution of carbonate. It is thus of crucial importance to drill a good, open-ocean site isolated from such influence, where subarctic IRD and environmental changes can be properly assessed.

The Iceland Sea is the final station for deep-water production, and modification of deep waters formed in the Greenland Sea and in the Arctic Ocean, before the deep waters are exported into the North Atlantic. Results from this drill site were considered necessary in order to determine the timing, evolution, and variations of these water masses.

The site is located on crust of middle or early Miocene age and is overlain by $216 \mathrm{~m}$ of sediment, allowing high-resolution studies throughout the past 10-12 m.y. Piston cores document Pleistocene pelagic carbonate sequences with pronounced glacial-interglacial cycles and ash layers. 


\section{Additional Considerations}

\section{Sea Ice}

The Yermak Plateau and Fram Strait sites are located near a region with close to year-round sea-ice cover. Sea ice was the potentially largest operational concern for drilling the proposed sites. From studies of the average August and September sea-ice conditions (Vinje, 1977) and expected sea-ice hazards, it appeared that, in the worst ice years, all proposed sites from these areas might potentially be affected by ice. However, the likelihood for ice concerns in the August to mid-September window was low. It was concluded, from this, that the major portions of the drilling program could be accomplished in normal years, including some of the Arctic sites, and all sites could be drilled in good ice years. Thus the chances of success were good, and the importance of drilling these frontier regions for the first time certainly made it worthwhile. To drill under the most optimal sea-ice conditions, an ice-forecast/ice-surveillance program was implemented, and an ice picket boat employed. After careful consideration, the Finnish icebreaker Fennica was selected and chartered for this purpose.

\section{Weather}

Although the proposed sites were located in high-latitude areas, weather conditions in the summer weather-window (July-September) were not particularly adverse and did not pose any threat to the success of the drilling program. DSDP Leg 38 and ODP Legs 104, 105,151 , and 152 were all conducted without weather problems. Recent drilling in the Southern Ocean has proven the capabilities of the JOIDES Resolution to provide excellent results under much harsher weather conditions than those expected for the summer season in the Norwegian-Greenland Sea and Arctic Ocean.

\section{SCOPE OF SCIENTIFIC RESULTS OF LEG 151}

The major theme of the NAAG program of ODP was oriented toward the paleoceanographic history of an area which is of high importance for the paleoclimatic evolution of the Northern Hemisphere during the late Cenozoic. As a consequence, the scientific topics taken up in the Scientific Results volume are oriented toward a number of major themes that are important in addressing this topic.

\section{Pelagic Biochronology}

Despite the dominantly terrigenous components of the sediments penetrated during Leg 151, planktonic and benthic microfossils were found at all sites and in sufficient quantity for a successful stratigraphic correlation to be developed. Major emphasis was paid to all aspects of pelagic biochronology, using calcareous nannofossils, planktonic foraminifers, diatoms, and radiolarians as well as organicwalled microfossils for the biostratigraphic framework of the drill sites. Particularly interesting information was gathered from benthic organisms such as foraminifers and ostracodes.

\section{Sedimentology}

The dominantly terrigenous sediments and their properties and composition reveal the response of the depositional environment to the paleoclimatic changes of the late Cenozoic that affected the Norwegian-Greenland Sea and the adjacent Arctic Ocean. Beside compositional studies, particular emphasis has been paid to geochemistry and physical properties, revealing, among other things, the peculiar Milankovitch frequency-related changes of the physical properties of the sediments.

\section{Plate Tectonics and Volcanic Topics}

As some of the drill sites are located close to Iceland and in locations of special tectonic interest, some very important contributions can be made toward the magmatic activity of the Norwegian-Greenland Sea, as well as the tectonic evolution of the northern gateway (Fram Strait) during the late Cenozoic. Particularly detailed information about the frequency and composition of the ash layers in Site 907 gives some interesting insight into the sequence of ash falls, mainly from Icelandic sources but maybe also in part from Jan Mayen (a volcano to the north of this drill site active during the latest Cenozoic). The drill sites in Fram Strait (from Hovgård Ridge and in the deep part of Fram Strait) provide information that addresses the origin of this important gateway, in particular its early history when it consisted of small and isolated basins.

\section{Paleoceanography}

The information from all chapters is combined into a paleoceanographic synthesis, which provides a major step forward in our understanding of the paleoenvironmental history of the Norwegian-Greenland Sea and the gateways to the ocean basins north and south of it. After Leg 104 addressed the paleoenvironmental history of the eastern Norwegian-Greenland Sea (including the history of the Norwegian Current, cf. Thiede et al., 1989), it was particularly interesting to address the history of the central and western part of the NorwegianGreenland Sea, including the East Greenland Current, the water exchange between the Norwegian-Greenland Sea and the Arctic Ocean, and the Arctic Ocean paleoenvironment on Yermak Plateau.

\section{ACKNOWLEDGMENTS}

The scientific results of this leg would not have been produced without the help and assistance of a number of people. First of all the proposals of the individual drill sites from various research institutions in some of the Scandinavian countries and Germany, as well as England, must be mentioned. The proposals were amalgamated into a drilling program by a Detailed Planning Group of the JOIDES advisory system, headed by W.F. Ruddiman. The drilling operations were carried out in late summer 1993 by the drilling superintendent of ODP (E.C. Pollard), of the Overseas Drilling Ltd. Sedco Forex Co. (R.C. Caldow), and by the crew of the SEDCO/BP 471 (JOIDES Resolution) under the command of Captain T. Ribbens. During Leg 151 the JOIDES Resolution was accompanied by the Finnish icebreaker Fennica under the able command of Captain J. Kyröhonka.

ODP is supported by an international consortium of participating nations and its international success is documented by the importance of the scientific results obtained by its famous drilling vessels. Drilling in the Norwegian-Greenland Sea was carried out in the interest spheres of a number of nations and we gratefully acknowledge drilling permits and the advice of Greenland (Denmark), Iceland, and Norway.

During the drilling operations early in Leg 151, one of the crew members fell ill and assistance had to be called in from the Iceland Coast Guard. Two helicopters and a fixed-wing aircraft from the U.S. Air Force base at Keflavik flew the patient to a hospital in Reykjavik.

Finally, this book was produced with the assistance of the editorial staff of the Ocean Drilling Program. ODP itself contributed greatly to the success of the leg through its highly qualified group of technicians on board the JOIDES Resolution, and in its participation in many ways in the final presentation of these results.

The satellite image of Figure 13 was provided by S. Sandven (Nansen Environmental and Remote Sensing Center), Bergen, Norway. 


\section{REFERENCES}

Aagaard, K., and Carmack, E.C., 1994. The Arctic Ocean and climate: a perspective. In Johannessen, O.M., Muench, R.D., and Overland, J.E. (Eds.), The Polar Oceans and Their Role in Shaping the Global Environment. Geophys. Monogr., Maurice Ewing Ser., Am. Geophys. Union, 85:5-20.

Aagaard, K., Swift, J.H., and Carmack, E.C., 1985. Thermohaline circulation in the Arctic Mediterranean seas. J. Geophys. Res., 90:4833-4846.

Boldreel, L.O., and Andersen, M.S., 1993. Late Paleocene to Miocene compression in the Faeroe-Rockall area. In Parker, J.R. (Ed.), Petroleum Geology of Northwest Europe. Proc. 4th Conf. Petrol. Geol., Geol. Soc. London, 2:1025-1034.

Bott, M.H.P., 1983a. The crust beneath the Iceland-Faeroe Ridge. In Bott, M.H.P., Saxov, S., Talwani, M., and Thiede, J. (Eds.), Structure and Development of the Greenland-Scotland Ridge. NATO Conf. Ser. IV, 63-75.

1983b. Deep structure and geodynamics of the Greenland-Scotland Ridge: an introductory review. In Bott, M.H.P., Saxov, S., Talwani, M., and Thiede, J. (Eds.), Structure and Development of the GreenlandScotland Ridge. NATO Conf. Ser. IV, 3-9.

Broecker, W.S., 1995. The Glacial World According to Wally: Palisades (Eldigio Press)

Broecker, W.S., and Denton, G.H., 1990. What drives glacial cycles? Sci. Am., 262:48-56.

Crane, K., Eldholm, O., Myhre, A.M., and Sundvor, E., 1982. Thermal implications for the evolution of the Spitsbergen transform fault. Tectonophysics, 89:1-32.

Creager, J.S., Scholl, D.W., et al., 1973. Init. Repts. DSDP, 19: Washington (U.S. Govt. Printing Office).

Duncan, R.A, Larsen, H.C., Allan, J.F., et al., in press. Proc. ODP, Init. Repts., 163: College Station, TX (Ocean Drilling Program).

Eldholm, O., 1990. Paleogene North Atlantic magmatic-tectonic events: environmental implications. Mem. Soc. Geol. Ital., 44:13-28.

1991. Magmatic-tectonic evolution of a volcanic rifted margin. Mar. Geol., 102:43-61.

Eldholm, O., Faleide, J.I., and Myhre, A.M., 1987. Continent-ocean transition at the western Barents Sea/Svalbard continental margin. Geology, 15:1118-1122.

Eldholm, O., Karasik, A.M., and Reksnes, P.A., 1990. The North American plate boundary. In Grantz, A., Johnson, G.L., and Sweeney, J.F. (Eds.), The Arctic Ocean Region. Geol. Soc. Am., Geol. of North Am. Ser., L:171-184.

Eldholm, O., and Myhre, A.M., 1977. Hovgaard Fracture Zone. Aarb., Nor. Polarinst., 1976:195-208.

Eldholm, O., Skogseid, J., Sundvor, E., and Myhre, A.M., 1990. The Norwegian-Greenland Sea. In Grantz, A., Johnson, L., and Sweeney, J.L. (Eds.), The Arctic Ocean Region. Geol. Soc. Am., Geol. of North America Ser., L:351-364.

Eldholm, O., Thiede, J., Taylor, E., et al., 1987. Proc. ODP, Init. Repts., 104: College Station, TX (Ocean Drilling Program).

1989. Proc. ODP, Sci. Results, 104: College Station, TX (Ocean Drilling Program).

Eldholm, O., and Thomas, E., 1993. Environmental impact of volcanic margin formation. Earth Planet. Sci. Lett., 117:319-329.

Eldholm, O., and Windisch, C.C., 1974. Sediment distribution in the Norwegian-Greenland Sea. Geol. Soc. Am. Bull., 85:1661-1676.

Feden, R.H., Vogt, P.R., and Flemming, H.S., 1979. Magnetic and bathymetric evidence for the "Yermak" hot spot northwest of Svalbard in the Arctic Basin. Earth Planet. Sci. Lett., 44:18-38.

Frakes, L.A, 1979. Climate Throughout Geological Time: New York (Elsevier).

Funder, S., Abrahamsen, N., Bennike, O., and Feyling-Hanssen, R.W., 1985. Forested Arctic: evidence from North Greenland. Geology, 13:542-546.

Gascard, J.C., Kergomard, C., Jeannin, P.F., and Fily, M., 1988. Diagnostic study of the Fram Strait marginal ice zone during summer from 1983 and 1984 Marginal Ice Zone Experiment Lagrangian Observations. J. Geophys. Res., 93:3613-3641.

Harland, W.B., 1969. Contribution of Spitsbergen to understanding of tectonic evolution of North Atlantic region. In Kay, M. (Ed.), North Atlantic: Geology and Continental Drift. AAPG Mem., 12:817-851.

Hinz, K., Eldholm, O., Block, M., and Skogseid, J., 1993. Evolution of North Atlantic volcanic continental margins. In Parker, J.R. (Ed.), Petroleum Geology of Northwest Europe. Proceedings of the 4th Conference. Geol. Soc. London, 901-913.
Jackson, H.R., Johnson, G.L., Sundvor, E., and Myhre, A.M., 1984. The Yermak Plateau: formed at a triple junction. J. Geophys. Res., 89:32233232.

Jansen, E., Raymo, M.E., and Blum, P., et al., 1996. Proc. ODP, Init. Repts., 162: College Station, TX (Ocean Drilling Program).

Koltermann, K.P., 1987. Die Tiefenzirkulation der Grönland-See als Folge des thermohalinen Systems des Europäischen Nordmeeres (Diss. Naturwiss.). Fachbereich Geowissenschaften Univ. Hamburg.

Kristoffersen, Y., 1990a. On the tectonic evolution and paleoceanographic significance of the Fram Strait gateway. In Bleil, U., and Thiede, J. (Eds.), Geological History of the Polar Oceans: Arctic versus Antarctic. NATO ASI Ser., Ser. C, 308:63-76.

1990b. Eurasian Basin. In Grantz, A., Johnson, L., and Sweeney, J.L. (Eds.), The Arctic Ocean Region. Geol. Soc. Am., Geol. of North Am. Ser., L:365-378.

Kulm, L.D., von Huene, R., et al., 1973. Init. Repts. DSDP, 18: Washington (U.S. Govt. Printing Office).

Kutzbach, J.E., Prell, W.L., and Ruddiman, W.F., 1993. Sensitivity of Eurasian climate to surface uplift of the Tibetan Plateau. J. Geol., 101:177190.

Lamb, H.H., 1972. Climate: Present, Past and Future. (Vol. 1): London (Methuen).

Larsen, H.C., Saunders, A.D., Clift, P.D., Beget, J., Wei, W., Spezzaferri, S., and the ODP Leg 152 Scientific Party, 1994. Seven million years of glaciation in Greenland. Science, 264:952-955.

Lawver, L.A., Gahagan, L.M., and Coffin, M.F., 1992. The development of paleoseaways around Antarctica. In Kennett, J.P., and Warnke, D.A. (Eds.), The Antarctic Paleoenvironment: a Perspective on Global Change. Am. Geophys. Union, Antarct. Res. Ser., 56:7-30.

Lawver, L.A., Müller, R.D., Srivastava, S.P., and Roest, W., 1990. The opening of the Arctic Ocean. In Bleil, U., and Thiede, J. (Eds.), Geological History of the Polar Oceans: Arctic versus Antarctic: Dordrecht (Kluwer Academic Publ.), 29-62.

Mudge, D.C., and Rashid, B., 1987. The geology of the Faeroe Basin area. In Brooks, J., and Glennie, K. (Eds.), Petroleum Geology of Northwest Europe: London (Graham and Trotman), 751-763.

Myhre, A.M., and Eldholm, O., 1988. The western Svalbard margin ( $74^{\circ}-$ $80^{\circ}$ N). Mar. Pet. Geol., 5:134-156.

Myhre, A.M., Eldholm, O., Faleide, J.I., Skogseid, J., Gudlaugsson, S.T., Planke, S., Stuevold, L.M., and Vaagnes, E., 1992. Norway-Svalbard continental margin: structural and stratigraphical styles. In Poag, C.W., and de Graciansky, P.C. (Eds.), Geologic Evolution of Atlantic Continental Rises: New York (Van Nostrand Reinhold), 157-185.

Myhre, A.M., Eldholm, O., and Sundvor, E., 1982. The margin between Senja and Spitsbergen fracture zones: implication from plate tectonics. Tectonophysics, 89:33-50.

Myhre, A.M., Skogseid, J., Karlberg, T., and Eldholm, O., 1995. Tectonic evolution of Fram Strait Gateway in view of ODP Leg 151 results. 5th Inter. Conf. Paleoceanogr. (Abstract)

Myhre, A.M., and Thiede, J., 1995. North Atlantic-Arctic Gateways. In Myhre, A.M., Thiede, J., Firth, J.V., et al., Proc. ODP, Init. Repts., 151: College Station, TX (Ocean Drilling Program), 5-26.

Myhre, A.M., Thiede, J., Firth, J.V., et al., 1995. Proc. ODP, Init. Repts., 151: College Station, TX (Ocean Drilling Program).

Nilsen, T.H., 1983. Influence of the Greenland-Scotland Ridge in the geological history of the North Atlantic and Norwegian-Greenland Sea areas. In Bott, M.H.P., Saxov, S., Talwani, M., and Thiede, J. (Eds.), Structure and Development of the Greenland-Scotland Ridge. NATO Conf. Ser. IV, 457-478.

Perry, R.K., 1986. Bathymetry. In Hurdle, B.G. (Ed.), The Nordic Seas: New York (Springer), 211-234.

Perry, R.K., Fleming, H.S., Cherkis, N.Z., Feden, R.H., and Vogt, P.R., 1980. Bathymetry of the Norwegian-Greenland and Western Barents Seas: Washington (Naval Research Laboratory).

Perry, R.K., Fleming, H.S., Fleming, J.R., Weber, Y., Kristoffersen, J.K., Hall, A., Grantz, A., and Johnson, G.L., 1985. Bathymetry of the Arctic Ocean (scale 1:6,000,000): Washington (Naval Research Laboratory).

Rea, D.K., Basov, I.A., Janecek, T.R., Palmer-Julson, A., et al., 1993. Proc. ODP, Init. Repts., 145: College Station, TX (Ocean Drilling Program).

Rea, D.K., Basov, I.A., Scholl, D.W., and Allan, J.F. (Eds.), 1995. Proc. ODP, Sci. Results, 145: College Station, TX (Ocean Drilling Program).

Ridd, M.F., 1983. Aspects of the Tertiary geology of the Faeroe-Shetland Channel. In Bott, M.H.P., Saxov, S., Talwani, M., and Thiede, J. (Eds.), Structure and Development of the Greenland-Scotland Ridge. NATO Conf. Ser. IV, 91-109. 
Roberts, D.G., Bott, M.H.P., and Uruski, C., 1993. Structure and origin of the Wyville-Thomson Ridge. In Bott, M.H.P., Saxov, S., Talwani, M., and Thiede, J. (Eds.), Structure and Development of the Greenland-Scotland Ridge. NATO Conf. Ser. IV, 133-158.

Ruddiman, W.F., and JOIDES NAAG-DPG, 1991. North Atlantic-Arctic Gateways. JOIDES J., 17:38-50.

Sætre, R., and Mork, M. (Eds.), 1981. The Norwegian coastal current (Vols. 1 and 2). Proc. Norw. Coastal Current Symp.

Schlosser, P., Bonisch, G., Rhein, M., and Bayer, R. 1991. Reduction of deepwater formation in the Greenland Sea during the 1980s: evidence from tracer data. Science, 251:1054-1056.

Shackleton, N.J., Backman, J., Zimmerman, H., Kent, D.V., Hall, M.A., Roberts, D.G., Schnitker, D., Baldauf, J.G., Desprairies, A., Homrighausen, R., Huddlestun, P., Keene, J.B., Kaltenback, A.J., Krumsiek, K.A.O., Morton, A.C., Murray, J.W., and Westberg-Smith, J., 1984. Oxygen isotope calibration of the onset of ice-rafting and history of glaciation in the North Atlantic region. Nature, 307:620-623.

Skogseid, J., 1994. Dimensions of the Late Cretaceous-Paleocene Northeast Atlantic rift derived from Cenozoic subsidence. Tectonophysics, 240:225-247.

Skogseid, J., Pedersen, T., Eldholm, O., and Larsen, B.T., 1992. Tectonism and magmatism during NE Atlantic continental break-up: the Vøring Margin. In Storey, B.C., Alabaster, T.C., and Pankhurst, R.J. (Eds.), Magmatism and the Causes of Continental Break-up. Geol. Soc. Spec. Publ. London, 68:303-318.

Srivastava, S.P., 1985. Evolution of the Eurasian Basin and its implications to the motion of Greenland along Nares Strait. Tectonophysics, 114:2953.

Srivastava, S.P., Arthur, M., Clement, B., et al., 1987. Proc. ODP, Init. Repts., 105: College Station, TX (Ocean Drilling Program).

Srivastava, S.P., Arthur, M.A., Clement, B., et al., 1989. Proc. ODP, Sci. Results, 105: College Station, TX (Ocean Drilling Program),

Talwani, M., and Eldholm, O., 1972. The continental margin off Norway. Geol. Soc. Am. Bull., 83:3575-3608.

1977. Evolution of the Norwegian Greenland Sea. Geol. Soc. Am Bull., 88:969-999.

Talwani, M., Udintsev, G., et al., 1976. Init. Repts. DSDP, 38: Washington (U.S. Govt. Printing Office).

Thiede, J., and Eldholm, O., 1983. Speculations about the paleodepth of the Greenland-Scotland Ridge during late Mesozoic and Cenozoic times. In Bott, M.H.P., Saxov, S., Talwani, M., and Thiede, J. (Eds.), Structure and Development of Greenland-Scotland Ridge. NATO Conf. Ser. IV: New York (Plenum), 445-456.

Thiede, J., Eldholm, O., and Taylor, E., 1989. Variability of Cenozoic Norwegian-Greenland Sea paleoceanography and Northern Hemisphere paleoclimate: synthesis of paleoenvironmental studies of ODP Leg 104, Vøring Plateau, Norwegian continental margin. In Eldholm, O., Thiede,
J., Taylor, E., et al., Proc. ODP, Sci. Results, 104: College Station, TX (Ocean Drilling Program), 1067-1118.

Thiede, J., and NAD Science Committee, 1992. The Arctic Ocean record: key to global change (initial science plan). Polarforschung, 61:1-102.

Turner, J.D., and Scrutton, R.D., 1993. Subsidence patterns in western margin basins: evidence from the Faeroe-Shetland Basin. In Parker, J.R. (Ed.), Petroleum Geology of Northwest Europe. Proc. 4th Conf. Petrol. Geol., Geol. Soc. London, 2:975-983.

Vinje, T.E., 1977. Sea-ice conditions in the European sector of the marginal seas of the Arctic, 1966-75. Aarb., Nor. Polarinst., 1975:163-174.

Vogt, P.R., 1986a. Geophysical and geochemical signatures and plate tectonics. In Hurdle, B.G. (Ed.), The Nordic Seas: New York (Springer-Verlag), 413-662.

, 1986b. Seafloor topography, sediments, and paleoenvironments In Hurdle, B.G. (Ed.), The Nordic Seas: New York (Springer-Verlag), $237-412$.

Vogt, P.R., Johnson, G.L., and Kristjansson, L., 1980. Morphology and magnetic anomalies north of Iceland. J. Geophys., 47:67-80.

Vogt, P.R., Perry, R.K., Feden, R.H., Fleming, H.S., and Cherkis, N.Z., 1981. The Greenland-Norwegian Sea and Iceland environment: geology and geophysics. In Nairn, A.E.M., Churkin, M., and Stehli, F.G. (Eds.), The Oceans Basins and Margins (Vol. 5): The Arctic Ocean: New York (Plenum), 493-598.

Vogt, P.R., Taylor, P.T., Kovacs, L.C., and Johnson, G.L., 1979. Detailed aeromagnetic investigation of the Arctic basin. J. Geophys. Res., 84:10711089.

Warnke, D.A., and Hansen, M.E., 1977. Sediments of glacial origins in the area of DSDP Leg 38 (Norwegian-Greenland seas): preliminary results from Sites 336 and 344. Naturforsch. Ges. Freib. Breisgau Ber., 67:371392.

White, R., and McKenzie, D., 1989. Magmatism at rift zones: the generation of volcanic continental margins and flood basalts. J. Geophys. Res. 94:7685-7729.

Wold, C.N., Hay, W.W., Dullo, W.-C., Wolf, T.C.W., and Bruns, P., 1993. Oligozäne Paläo-Ozeanographie des Grönland-Schottland-Rückens. Geowiss., 11:353-359.

Wolf, T.C.W., and Thiede, J., 1991. History of terrigenous sedimentation during the past 10 m.y. in the North Atlantic (ODP Legs 104 and 105 and DSDP Leg 94). Mar. Geol., 101:83-102.

Date of initial receipt: 7 March 1996

Date of acceptance: 22 May 1996

Ms 151SR-100 